\title{
Chapter 2 \\ A Model of Critical Thinking in Higher Education
}

\author{
Martin Davies
}

\section{Part 1: The Individual Axis}

\section{Introduction}

"Critical thinking in higher education" is a phrase that means many things to many people. It is a broad church. Does it mean a propensity for finding fault? Does it refer to an analytical method? Does it mean an ethical attitude or a disposition? Does it mean all of the above? Educating to develop critical intellectuals and the Marxist concept of critical consciousness are very different from the logician's toolkit of finding fallacies in passages of text, or the practice of identifying and distinguishing valid from invalid syllogisms. Critical thinking in higher education can also encompass debates about critical pedagogy, i.e., political critiques of the role and function of education in society, critical feminist approaches to curriculum, issues related to what has become known as critical citizenship, or any other education-related topic that uses the appellation "critical". Equally, it can, and usually does, refer to the importance and centrality of developing general skills in reasoning - skills that we hope all graduates possess. Yet, despite more than four decades of dedicated scholarly work "critical thinking" remains as elusive as ever. As a concept, it is, as Raymond Williams has noted, a 'most difficult one' (Williams, 1976, p. 74).

\footnotetext{
M. Davies, Ph.D. ( $ه)$

Melbourne Graduate School of Education, University of Melbourne, 234 Queensbury Street,

Carlton, VIC, Australia

e-mail:wmdavies@unimelb.edu.au
} 
How should we account for these issues when we-i.e., academics, educators, employers, interested others-make bold claims about the importance of our students developing "critical thinking"? There is little doubt that critical thinking in higher education involves all of the elements noted above. But what sense can be made of this? Critical thinking cannot be all things to all people; this would mean the phrase does little useful scholarly work.

Traditional philosophical definitions of the concept of "critical thinking"which I shall outline shortly-do not necessarily inform debates in these very different areas of critical thinking scholarship. Definitions of critical thinking are not central to areas such as critical pedagogy or critical feminism. Learning about them does not help one develop a critical attitude about the society in which one lives. Philosophical definitions of critical thinking do not assist in becoming a critical citizen. However, in another sense, the core attributes of critical thinking canvassed in these definitions will always remain fundamental to what we mean by "critical thinking". At a very basic level, critical thinking is about having skills of a certain sort (inference making, reasoning, and so on). Yet, critical thinking is also much more than this. Traditional philosophical definitions of critical thinking seem impotent in relation to these wider areas of critical thinking scholarship as they apply to the discipline of Higher Education.

Whether critical thinking can and should be taught is as contested as the concept of "critical thinking" itself. Again, any answer to these questions depends very much on what one means by "critical thinking". Many would concur that teaching the skill of recognizing and constructing arguments-i.e., critical thinking as reasoning skills_-is valuable and important. However, educating for radical social and political change (i.e., "critical pedagogy") may be seen as less desirable. Others are not happy with the teaching of critical thinking in any form. Consider, for example, the recent Texas Republican Party policy that explicitly tried to ban the teaching of critical thinking in schools (Strauss, 2012). Banning something is premised on a clear understanding of the thing one is trying to ban. But what exactly did the Republicans want to ban? This was not obvious. Little progress on the topic of critical thinking in higher education can be made if the concept itself remains unmoored from any proper theoretical and conceptual grounding. Little progress can be made if "critical thinking" remains un-theorized. Perhaps this is why critical thinking is said to be 'one of the defining concepts in Western education which enjoys wide endorsement, yet we have no proper account of it' (Barnett, 1997, p. 1).

It is probably about time that we had such an account. Accordingly, this two-part paper aims to provide a holistic conception of the various theoretical approaches to critical thinking as it is used in the discipline of Higher Education. I develop a model of critical thinking in higher education that pays due recognition to the antecedent work done by others (in the so-called "critical thinking movement", and elsewhere), and yet which provides a place for work being done in a variety of fields residing at the periphery of traditional critical thinking scholarship in Higher Education. 


\section{Models of Critical Thinking}

Building on the work of Barnett (1997), the suggestion is that critical thinking in higher education has at least six distinct, yet integrated and permeable, dimensions (see Part 2, "A model of critical thinking in higher education"). These range from: (1) core skills in critical argumentation (reasoning and inference-making), (2) critical judgments, (3) critical thinking dispositions and attitudes, (4) critical actions, (5) critical social relations, and (6) what I, and others (notably, Burbules \& Berk, 1999), call "critical creativity", "critical openness", or critical being. Each of these, I submit, has an important place in an overarching model of critical thinking. The model I propose will demonstrate that critical thinking has both an individual, as well as a socio-cultural dimension-both comprising axes in the model-and admits of at least six distinct, dimensions of critical thinking: i.e., as skills, judgments, dispositions, actions, social relations and critical being. This helps in developing a theory of critical thinking in higher education, with due acknowledgment to past and present approaches to the topic. This has the potential to assist in making headway on the variety of critical thinking concerns that exist in the field of Higher Education today.

There are many well-developed extant models of critical thinking. They might be called "philosophical" models of critical thinking. They range from the tried and tested taxonomy of educational objectives, with its contemporary variations (Airasian et al., 2001; Bloom, 1956) to the Collegiate Learning Assessment, APA Delphi and Paul-Elder models (Facione, 1990; Paul \& Elder, 2001; Sadler, 2010). There are also models of critical thinking in relation to cognitive decision-making (Ennis, 1991). However, these models are used mostly in educating for critical thinking; i.e., aiming to provide a solid cognitive foundation for judgment formation and decision-making. However, critical thinking in higher education is a different beast, serving as it does, the entire interdisciplinary field of Higher Education, and the wider concerns of educators' attitudes to criticality. Concerns about argumentation, judgment formation and decision-making that bears on educating for criticality also apply to critical thinking in higher education, but the latter has a wider brief.

It is the latter which is my main focus. Just as critical thinking has a different place in the various disciplines - critical thinking in the sciences is different from the professions - so too there is unique place for critical thinking in Higher Education. In this paper I attempt to locate this place. Any account of the place of critical thinking in higher education needs to make sense, for example, of how critical thinking is represented in debates about critical pedagogy, the role of education in leading to individual and collective socio-political activism, the place of critical thinking in educating for citizenship, the role of critical thinking in relation to creativity, and so on. Any such account of critical thinking must also account for the traditional focus of critical thinking as a composite of skills and judgments, and as a variety of dispositions as well. A model of critical thinking in higher education is needed that incorporates all these concerns. 
These varied higher educational concerns, I suggest, are not well-served by present models of critical thinking. The latter have a very different, and circumscribed, purpose. While philosophical accounts of critical thinking may be necessary in relation to one important purpose in higher education (teaching important cognitive skills), they are not sufficient in accounting for the place of critical thinking in the discipline of Higher Education. The latter is what I aim to provide in this paper.

\section{The Place of Critical Thinking in Higher Education}

What is the place of critical thinking in higher education? At one level critical thinking is all about the development of certain sorts of skills. These include skills in argumentation, and skills in making sound judgments. Employers want evidence of critical thinking skills in their employees, and graduates are assumed to possess these skills. However, skills without the disposition to use them are not much use, so critical thinking is about dispositions as well. Critical thinking, as both skills and dispositions, is mainly about the development of the individual. We might call this the individual dimension of critical thinking.

Critical thinking in this sense is needed by industry as much as academia. But, of course, society also demands individual critical thinking skills and dispositions as these are important for employment and wider social and political engagement. Critical thinking is, therefore, both an individual attribute and beneficial to society. Can we say then, that critical thinking is a social aspiration as well, i.e., that it has a social dimension?

Theorists that promulgate views in what has become known as critical pedagogy think that critical thinking is as much about changing society, and conditions of social oppression, as much as demonstrating individual skills in reasoning, argumentation and judgments. They regard belief claims, for example, 'not merely as a propositions to be assessed for their truth content, but as part of systems of belief and action that have aggregate effects within the power structures of society. It asks first about these systems of belief and action, who benefits?' (Burbules \& Berk, 1999, p. 47). Their focus is not on individual skills and dispositions as much as the social and political relevance of arguments and reasoning. Questioning power relationships in society must, they argue, be considered a central part of critical thinking (Kaplan, 1991).

Similarly, scholars that write about what has become known as critical democratic citizenship education have a very different account of critical thinking. Given that critical thinking has a social and political dimension, it is not unreasonable for it to have a dimension of inter-personal socially-appropriate caring as well (Noddings, 1992). In order to cultivate critical citizens, they argue, 'instructional designs are needed that do not capitalize on applying tricks of arguing, nor on the cognitive activity of analyzing power structures, but contribute ... in a meaningful and critical way in concrete real social practices and activities' 
(Ten Dam \& Volman, 2004, p. 371). They argue that learning to think critically should —in part at least—be conceptualized as 'the acquisition of the competence to participate critically in the communities and social practices of which a person is a member' (Ten Dam \& Volman, p. 375). This kind of educational aim, naturally, has an impact on the development of critical character and virtue. A good "citizen", they suggest, should be more than an individual, who is well-appraised of skills in argumentation with the capacity to form sound judgments, but a socially-adept and virtuous person, caring in nature, with the capacity to consider the interests and needs of his fellow man. Critical thinking therefore has moral as well as cultural characteristics. We might call this the socio-cultural dimension of critical thinking.

Both the individual and the socio-cultural dimensions can be given a place, and reconciled, in a single model of critical thinking in higher education. I see both dimensions as separate and distinguishable axes or vectors that account for very different, equally important, aspects of critical thinking. To date, much of the scholarly effort has been (rightly) expended on the individual axis, with its emphasis on the cultivation of skills and dispositions. This is understandable: being an (individual) critical thinker naturally has many personal and social benefits, not to mention its need in the workplace. Increasingly, however, more work is being done on the socio-cultural dimension. This too is important, albeit it is often neglected.

I begin by looking at the various, well-known definitions of the concept of critical thinking, and put these into a conceptual framework. Following this, I shall outline various views of critical thinking incorporating skills, judgments, dispositions, actions and social relations. In Part 2, I provide a model - a model of critical thinking in higher education - that incorporates all these dimensions.

\section{What Is Critical Thinking?}

The first thing to do is to gain an understanding of critical thinking as it applies in higher education. One way of doing this would be to take the strategy of isolating negative instances of critical thinking, i.e., to say what critical thinking is not. This helps to delimit the boundaries of the concept. Fortunately, there is little dispute on negative cases. Critical thinking is not:

- Purposeless thinking: Day-dreaming, musing and idle thinking is not critical thinking, "they do not qualify for the adjective "critical"' (McPeck, 1981, p. 3). Instead, it is agreed that critical thinking must be goal-directed, aimed towards an end, and purposeful.

- Random thinking: Careless, misdirected and sloppy thinking is not critical thinking either. Using questionable evidence, failure to assess sources, and relying on dubious authority is contrary to critical thinking (Bailin, Case, Coombs, \& Daniels, 1999). Critical thinking relies on meeting adequate standards.

- Accidental or unintentional thinking: Arriving inadvertently or unintentionally at the correct critical assessment of a position or the accomplishment of a goal is 
insufficient for critical thinking. Critical thinking must be done in full knowledge and awareness of the standards of thinking expected (even if these "standards" cannot necessarily be verbalized) (Bailin et al., 1999, p. 287). To put it in other terms, critical thinking is necessarily an 'intellectually disciplined process' (Scriven \& Paul, 1987). Mindless application of a set of logical principles "as an exercise" will not suffice. There must be some kind of metacognitive awareness as well (Mulnix, 2012, p. 465).

- Good thinking: Critical thinking can be exemplified in "good" thinking, but the relationship is asymmetrical: not all good thinking is an example of critical thinking. The concepts are not equivalent.

- Independent thinking: This can be seen in the same way as "good" thinking: the relationship is asymmetrical. One can think independently without thinking critically.

- Rational thinking: These are closely connected but not identical, and critical thinking is a facet of what it means to be "rational" (McPeck, 1981, p. 12).

- Problem-solving: While sometimes used interchangeably, critical thinking and problem-solving are not equivalent either. Not all critical thinking we do necessarily involves solving problems. The key here is that problem-solving involves making judgments in order to complete tasks. These judgments can either meet or fail to meet standards of critical thinking, so in solving a problem we may engage, or fail to engage, in critical thinking.

- Decision-making: This can be seen in the same way as "problem-solving": 'Problem solving decision making, etc., are best seen as arenas in which critical thinking should take place rather than other kinds of thinking to be contrasted with critical thinking' (Bailin et al., 1999, p. 288 italics mine).

- Higher-order thinking: This is a vague, umbrella term referring to 'critical, logical, reflective, metacognitive, and creative thinking' (King, Goodson, \& Rohani, n.d.). As a term with a wider ambit, it is not, by definition, identical to critical thinking which is narrower in scope.

- Logical, reflective, metacognitive thinking: These are aspects or elements of critical thinking as we shall see, but on their own not equivalent to critical thinking which has a broader ambit (see below).

- Creative thinking: A number of things can be the product of creative thinking: dances, dramatic work, poetry, scientific innovation, and so on. The differences are best summarized as follows: 'creativity masters a process of making or producing; criticality, a process of assessing or judging' (Paul \& Elder, 2008, p. 4). Creative thinking and critical thinking are (sometimes) inseparable kinds of thinking, but they not exactly the same. I shall return to creative thinking in Part 2.

- 'Intuitive' thinking: This is an ambiguous term. It can be considered in some sense as a form of creative thinking (if used synonymously), or random thinking (if used to mean "without reasons"). Neither are the same as critical thinking for reasons already provided. Interestingly, however, "intuitive" might also mean "beyond" reasons, or trans-critical, as in the case (say) of an accomplished sportsperson's placement of a ball or understanding of game strategy, or a 
mother's "intuition" that her child is unwell. This kind of "intuition" is often right, grounded in background knowledge, common lore, is evidence-based, rational (albeit not always consciously so), and so forth, and yet which does not seem synonymous with critical thinking, though an important part of it. (I shall return to this kind of thinking in Part 2.)

The second, more difficult, step to take would be to define critical thinking. This is not easy. Some years ago, one scholar remarked that: 'After reading the various definitions of critical thinking, it becomes clear that agreement upon a single, concise definition of this concept is difficult, if not impossible' (Skinner, 1976, p. 293). This led one theorist to claim that critical thinking was both "over-worked" and "under-analyzed" (McPeck, 1981, p. 2), and another to call the situation like being mired in a 'conceptual swamp' (Cuban, 1984, p. 686). However, the task of defining critical thinking has been attempted and the more well-known definitions of critical thinking proposed over the past few decades have included the following (in chronological order):

- ‘. . correct assessing of statements' (Ennis, 1962, p. 8)

- '.. the propensity and skill to engage in an activity to reflective skepticism' (McPeck, 1981, p. 8) ... 'the intelligent use of all available evidence for the solution of some problem' (McPeck, p. 12)

- '... reflective and reasonable thinking that is focused on deciding what to believe or do' (Ennis, 1985b, p. 45).

- ' . . the ability to analyze facts, generate and organize ideas, defend opinions, make comparisons, draw inferences, evaluate arguments and solve problems' (Chance, 1986, p. 6).

- '... to detect and avoid fallacious reasoning and to analyze deductive and inductive arguments' (Kurfiss, 1988, p. iii).

- 'active, systematic process of understanding and evaluating arguments' (Mayer \& Goodchild, 1990, p. 4)

- '... careful and deliberate determination of whether to accept, reject, or suspend judgment' (Moore \& Parker, 1991, p. 4).

- '... Thinking about your thinking while you're thinking to make your thinking better' (Paul, 1993, p. 91).

- '. . . thinking aimed at forming a judgment' where the thinking itself meets standards of adequacy and accuracy (Bailin et al., 1999, p. 287), or 'fulfilling relevant standards of critical assessment in carrying out thinking tasks’ (p. 291).

(For other definitions, see Fisher \& Scriven, 1997; Halpern, 1997, p. 4; Lipman, 1988, p. 39; Scriven \& Paul, 1987; Siegel, 1988, p. 25; Tama, 1989, p. 64).

Over the years, the plethora of definitions and distinctions expounded on the topic of critical thinking were thought to be a hindrance to clarity. This applied especially to the myriad of definitions developed during the first and second "waves" of the critical thinking movement in the 1970s and 1980s (Paul, 2011). Something clearly had to be done. 
The American Philosophical Association convened an authoritative panel of 46 noted experts on the subject, to produce a definitive account of the concept. It resulted in the production of the landmark Delphi Report (Facione, 1990). This led to the following definition of critical thinking; a definition which is as long and comprehensive as it is dense and hard to follow:

We understand critical thinking to be purposeful, self-regulatory judgment which results
in interpretation, analysis, evaluation and inference as well as explanation of the evidential
conceptual, methodological, criteriological or contextual considerations upon which that
judgment was based. Critical thinking is essential as a tool of inquiry. Critical thinking is
pervasive and self-rectifying, human phenomenon. The ideal critical thinker is habitually
inquisitive, well-informed, honest in facing personal biases, prudent in making judgments,
willing to consider, clear about issues, orderly in complex matters, diligent in seeking
relevant information, reasonable in selection of criteria, focused in inquiry and persistent
in seeking result which are as precise as the subject and circumstances of inquiry permit.
(Facione, 1990)

While of undeniable importance as a definition of critical thinking for educational philosophers, this account of critical thinking does not lend itself easily to educational decision-making. How would a Dean of a Faculty, for example, use this definition to further embed the teaching of critical thinking in the curriculum? How useful is it, in a practical sense, in a higher education context? It is not clear that higher education can benefit from such a definition in the form it is presented. Nor does it square with the wider concerns of higher education academics about the nature of criticality. It seems, on the face of it, a definition rooted in one kind of critical thinking (albeit an important one); namely, critical thinking as argumentation and judgment formation.

Of course, all definitions are limiting in some respects, and one definition will never satisfy everyone. It is not easy, it seems, to define critical thinking in a way which is both comprehensive and practically useful. As Facione (the Delphi report author) himself has wryly observed, defining "critical thinking" is something like trying to define "offensive violence". We may "know it when we see it", and be able to distinguish it from its opposite-i.e., illogical, irrational thinking-but refining our ideas further than this does not allow us to easily form a clear, and unambiguous definition that would be immediately helpful in a range of contexts (Facione, 1998) (See also Bailin et al., 1999, p. 285; McPeck, 1981, p. 1).

Others have claimed, however, that without clarifying the concept of critical thinking, educators risk 'shooting arrows at target we cannot see' (Mulnix, 2012, p. 464), so a definition of some kind-even if it is limiting-is better than none at all. All concur the task is difficult. (Mulnix herself takes the tack of defining critical thinking in its simplest, unadorned form as: 'acquiring, developing, and exercising the skill of being able to grasp inferential connections holding between statements' (Mulnix, pp. 464-465). This effectively reduces critical thinking merely to skills in logical reasoning — "logicality" — and nothing more. For reasons outlined earlier, this will not do as a definition for the purposes of critical thinking in Higher Education.)

The miasma of definitions of critical thinking cannot on their own guide the way to greater clarity. Some analysis and deconstruction of the definitions given above 
is therefore in order. I shall take the Delphi definition as the authoritative account. From this, I shall explore what it might mean if critical thinking is taken beyond customary definitions to include wider considerations, and what it might mean if all such considerations could be encompassed in an overarching model of critical thinking (see Part 2).

Among the various threads in the above definition, we can distinguish the following: critical thinking as skills in inference-making and argumentation; critical thinking as (reflective) judgment formation, and critical thinking as a variety of dispositions and attitudes. These can be broadly defined into two broad categories: cognitive elements (argumentation, inference-making and reflective judgment) and propensity elements (dispositions, abilities and attitudes) (Halonen, 1995). Note, however, the phenomenon of action is not mentioned in the Delphi definition. It is, in principle possible to meet the stipulated requirements of the definition and not do anything, i.e., not engage in critical activity of a physical kind. This will become important later. For now, let us look in more detail at each of the elements of the Delphi definition under the headings: namely, cognitive elements and propensity elements.

\section{Cognitive Elements to Critical Thinking}

The following account of the cognitive and propensity elements to critical thinking constitutes the approach of looking at critical thinking through what we might call a "philosophical" lens. In Part 2, I turn to a very different way of looking at critical thinking; namely, critical thinking through a "higher education" lens. They are very different approaches, although complementary, as we shall see. Later I shall propose a framework for the various positions in the critical thinking literature that encompasses both philosophical and higher education considerations on the topic. These positions will lie along certain axes or vectors on my model. The model will hopefully contextualize, and make clear, some of the very diverse work currently being undertaken under the auspices of "critical thinking in higher education".

\section{Critical Thinking as Argumentation (The "Skills" View)}

Critical thinking as argumentation is an essential skill for the reflective citizen as well as the student. Although, as discussed, there are varying definitions of "critical thinking" (Ennis, 1985a, 1990; Lipman, 1988; McPeck, 1981; Paul, 1992b), and considerable discussion over those definitions, for most purposes critical thinking can be defined-in part at least—as a skill, which can be learned, involving the intellectual activity of identifying, analyzing and evaluating arguments and propositions. I shall call this the "skills"-based view, or critical thinking as "logicality" (Burbules $\&$ Berk, 1999). Ennis, at one point, defines critical thinking as "correct assessing of statements' (Ennis, 1962, p. 8), later changing his definition to incorporate reflective judgment formation (see below, "Critical thinking as reflective thinking"). 
Identifying, analyzing and evaluating arguments and propositions is, of course, a fundamental skill that is increasingly expected of students by educators and employers in the "knowledge" economy and is thus of economic and social importance. A major theme of the recent text Academically Adrift, and the one that has received the most US media attention, is that higher education has not done enough for the improvement of students' critical thinking in the sense given above (Arum \& Roska, 2011). Today's students, it seems, are not as well prepared as they might be in their capacity to isolate, discuss, analyze and evaluate arguments. But why is this so important?

\section{Argumentation and Decision-Making}

Critical thinking as argumentation is ubiquitous in all professional and academic areas, but is particularly important in higher education. Higher education prepares people for employment, and instills in individuals the capacity to make reasoned arguments of all kinds throughout our lives_-both as a human being in a social or academic context, and later, as a member of a corporate or professional community as an employee.

As individuals, of course, we often face complex issues about which we must weigh evidence and come to conclusions. Eventually we might make decisions based on those conclusions. These need not be decisions about academic issues, of course, but may be fairly domestic and mundane, e.g., whether or not to send a child to a private or public school, whether or not to invest in property or shares, or whether to subscribe to a given social, political or sporting organization. In each case, as individuals we have to weigh competing arguments-i.e., propositions in support of a given contention, and/or objections to them-and arrive at wellreasoned decisions about the truth or falsity, or the likely plausibility of a conclusion. Critical thinking as argumentation also involves distinguishing validity of argument structure from the believability or soundness of premises, distinguishing fallacious reasoning from valid reasoning, and so on.

Corporations, similarly, also have to make decisions on the basis of strong and compelling arguments, e.g., whether, and on what terms, to make appointments or large purchasing decisions. Likewise, legal practitioners, compelled by arguments for or against a proposition, and underpinned by the weight of evidence, are often required to make judgments that affect the lives of others in a very dramatic wayfor example, whether or not to make a plea bargain in a criminal trial, or how, and under which circumstances, to advise a client when asked to articulate their guilt or innocence in a court of law. Medical doctors face similar difficult decisions, for example, deciding upon a course of treatment that may slow the progress of a disease yet potentially decrease the quality of a person's life. Governments also make important choices; for example, in relation to acquisition of expensive military equipment; or when making difficult, yet influential, decisions in the areas of public or foreign policy. These issues involve many arguments on both sides of difficult debates. Skills in argumentation are clearly essential in all areas of life. 
Strong skills in argumentation lead naturally to a sound basis for capable decision-making. This is because decision-making is based on judgments derived from argumentation. (As noted earlier, decision-making is best seen as 'an arena in which critical thinking takes place' i.e., as a forum for critical thinking, but not as critical thinking itself.) Such decision-making involves understanding and interpreting the propositions and arguments of others, and being able to make objections and provide rebuttals to objections. Broadly speaking, then, this sense of the term "critical thinking" is seen as involving skills in formal or informal argumentation. Critical thinking in this sense is a fundamental skill; a skill whichon the available evidence-universities have apparently not been teaching as well as they should.

The first and most basic form of cognitive critical thinking then is skills in argumentation. The aforementioned definition of critical thinking provided by Mulnix is most suited to this kind of skill. It is unadorned critical thinking as it were. It is critical thinking in its purest form.

\section{Critical Thinking as Reflective Thinking (The "Skills-and-Judgments" View)}

Critical thinking is often defined more generally than this, however, and in practical and instrumental terms, e.g., as: 'reflective and reasonable thinking that is focused on deciding what to believe or do' (Ennis, 1985b) or as 'thinking aimed at forming a judgment' (Bailin et al., 1999, p. 287) or as 'skillful, responsible thinking that facilitates good judgment' (Lipman, 1988, p. 39). This definition focuses less on the mechanics of the skill of argumentation, and more on the reflective basis for decision-making and judgment calls. We might call this the "skills-and-judgments" view.

These wider senses of critical thinking are not inconsistent with 'critical thinking as argumentation', of course, and are indeed, in some sense premised on it. Being able to demonstrate "reflective thinking" for the purposes of decision-making, of course, requires skills in argumentation. However, this account does put a slightly different emphasis on critical thinking, focusing less on mechanisms of argumentation qua inference-making, and more on judgment formation which is at a higher cognitive level. (The relationship seems asymmetric: one can engage in idle argumentation without making a judgment towards a decision, but not viceversa-or at least not ideally.)

This twist in emphasis is not insignificant, however. It marks a distinction between critical thinking as pure "logicality" (critical thinking as argumentation) and critical thinking — potentially at least—as involving much more than this. This observation will important when I come to look at critical thinking through the "higher education" lens. The relationship between the argumentation view and the skills-and-judgments view is represented in the diagram below. (Note that the dotted lines represent permeability. As we have seen, Ennis for one has articulated definitions in both spheres (Fig. 2.1). 


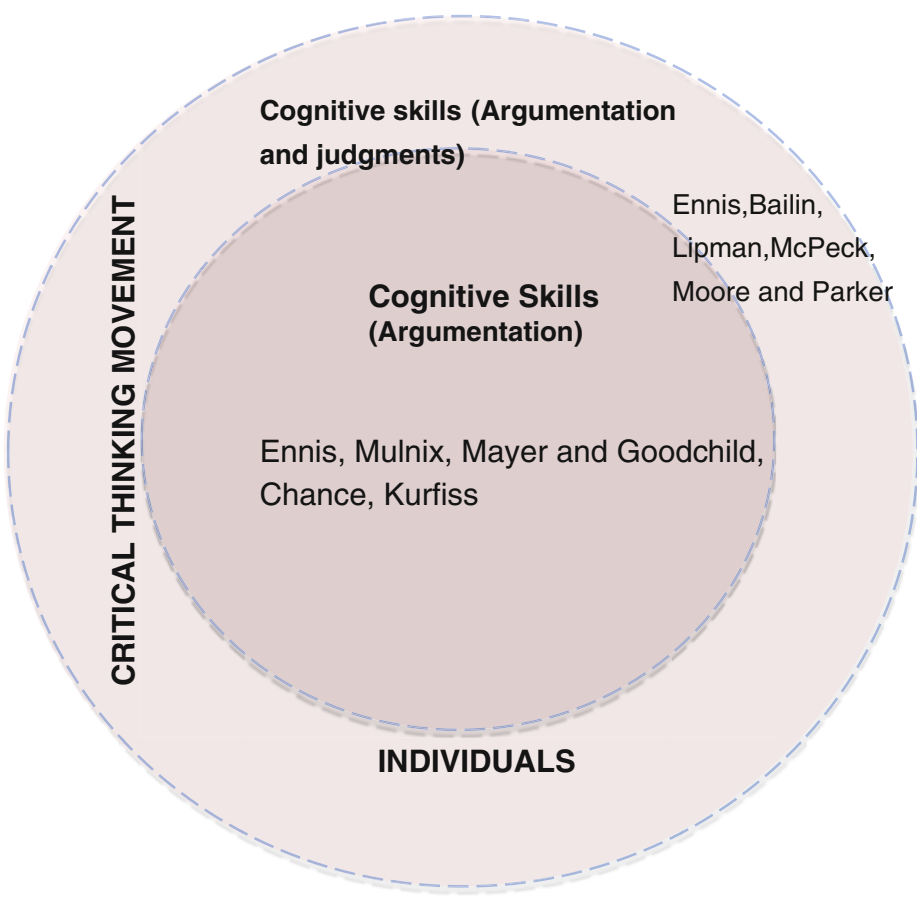

Fig. 2.1 The critical thinking movement

Both accounts are examples of critical thinking as it applies to individuals. They are also representative of work done as part of the so-called "critical thinking movement". A number of the aforementioned definitions provided earlier can be seen as amenable to this view of critical thinking as they all mention "skills" and/or "judgments" (see, for example, Bailin et al., 1999; Ennis, 1985b; Facione, 1998; Lipman, 1988; McPeck, 1981; Moore \& Parker, 1991). Others in the list provided earlier focus more on skills in argumentation simpliciter (Chance, 1986; Ennis, 1962; Kurfiss, 1988; Mayer \& Goodchild, 1990; Mulnix, 2012). Ennis is perhaps unique in having articulated published definitions of critical thinking encompassing both accounts (one being a development and an advance on the other).

The definition by Ennis, given above, i.e., 'reflective and reasonable thinking that is focused on deciding what to believe or do' is recognized as the established definition in the "skills-and-judgments" view. It is widely cited in the literature. However, note that Ennis' definition is somewhat limiting by not necessitating, for its application, any commitment to action on the part of the critical thinker. On Ennis' account, a person might exhibit critical thinking defined as 'reasonable and reflective thinking focused on deciding what to believe or do', without requiring that the decision actually be implemented (i.e., what philosophers, including Aristotle, call "weakness of the will") (Ennis, pers. comm. 2012). 
On Ennis' account “"deciding” is assumed to lead relatively unproblematically to the "doing" (Burbules \& Berk, 1999; Ennis, 1987). However, the "doing" is not specified in his account. The same applies to the comprehensive, all-inclusive account in the Delphi report as we have seen. Clearly, however, critical thinking in higher education should involve more than judging and deciding; it should involve some actual or potential commitment to action. Reasonable decision-making by itself, it seems, is not sufficient for critical thinking-in other words, critical thinking in higher education is not critical judgment in abstracto. I shall return to this point (see "Critical thinking as action" below).

The cognitive element of critical thinking can be seen as a composite of the following related, but quite different, skills and abilities:

- analysing arguments, claims or evidence (Ennis, 1985b; Facione, 1990; Halpern, 1998; Paul, 1992b);

- judging or evaluating arguments (Ennis, 1985b; Facione, 1990; Lipman, 1988; Tindal \& Nolet, 1995);

- making decisions or problem-solving (Ennis, 1985b; Halpern, 1998; Willingham, 2007);

- inference-making using a variety of standard reasoning patterns such as induction and deduction (Ennis, 1985b; Facione, 1990; Paul, 1992b; Willingham, 2007).

- predicting (Tindal \& Nolet, 1995);

- reasoning verbally (Halpern, 1998);

- interpreting and explaining (Facione, 1990);

- identifying assumptions (Ennis, 1985b; Paul, 1992b);

- defining terms (Ennis, 1985b); and

- asking questions for clarification (Ennis, 1985b).

Bloom's famous six-category schema of knowledge, comprehension, application, analysis, synthesis and evaluation, can be seen in terms of a forerunner of a cognitive approach to critical thinking, with critical thinking as argumentation occupying the latter three descriptors, where "evaluation" gives rise to making reasonable, reflective judgments (Bloom, 1956; Kennedy, Fisher, \& Ennis, 1991).

To this list we can add metacognition as a facet of critical thinking as cognitive skill. Although not a feature of argumentation per se, it is clearly necessary for it. People need to be 'brave enough to risk being wrong, and wise enough to realize that much can be learned from errors and failed solutions' (Nelson, 2005, p. xiv), and this involves thinking about our thinking. This can be defined as 'awareness of one's own thinking, awareness of the content of one's conceptions, an active monitoring of one's cognitive processes' (Hennessey, 1999, p. 3) or as 'the monitoring and control of thought' (Martinez, 2006, p. 696). Though there is some dispute as to the precise role played by metacognition in relation to critical thinking (some argue that it stands outside of critical thinking; others argue it is integral to it), there is little doubt that it is important for any adequate understanding of the concept (Halonen, 1995; Halpern, 1998; Kuhn, 1999; Kuhn \& Dean, 2004; van Gelder, 2005; Willingham, 2007). A recent attempt has been made to devise a comprehensive taxonomy of metacognition (Tarricone, 2011). 
To sum up the "skills and judgments" view in general terms, we can think of cognitive critical thinking skills as involving interpretation, analysis, inference, explanation, evaluation, and some element of metacognition or self-regulation (Facione, Sanchez, Facione, \& Gainen, 1995, p. 3; Halonen, 1995, pp. 92-93). These facets of critical thinking are all in the Delphi list. This is sometimes collectively known as the "skills-based" view of critical thinking-as distinct from the "skills-plus-dispositions" view, which I will discuss shortly. While the "skills and judgments" view involves more than skills in argumentation (it also involves reasoned judgments as we have seen) it is sometimes known simply as the "skillsbased" view in recognition of the fact that both skills and reflective judgments are both cognitive skills. Cognitive skills in critical thinking are at the core of the "philosophical" approach to the topic, and necessary-but not sufficient- to other accounts of critical thinking as well as we shall see.

An attempt has been made by the present author to plot the various skills proffered by various authors on the topic of critical thinking-from Bloom's taxonomy onwards-into a table and to cross-tabulate the results. This table is available online here [add].

\section{A Taxonomy of Critical Thinking Skills}

At this point categorizing these skills would seem to be useful. I shall use the framework by Wales and Nardi (1984), and borrowed by Halonen (1995), for this purpose. Cognitive critical thinking skills can be seen as falling under four main categories: lower-level thinking skills (which might be called "foundation" thinking), thinking skills (or "higher level" thinking), complex thinking skills, and thinking about thinking or metacognitive skills. "Identifying an assumption" for example, is clearly less difficult_ and requires fewer cognitive resources — than say "analysing a claim" or "drawing an inference". There might be debate about which skill belongs in which category, but there is little doubt some cognitive skills are demonstrably more sophisticated than others (Table 2.1).

There is considerable degree of unanimity in the literature on many the cognitive skills involved in critical thinking, if not the degree of importance accorded to each. In any event, the view that: (1) critical thinking is argumentation, and involves assessing statements, constructing and interpreting inferences, identifying flaws in

Table 2.1 Critical thinking skills

\begin{tabular}{l|l|l|l}
\hline $\begin{array}{l}\text { Lower-level thinking } \\
\text { skills ("Foundation") }\end{array}$ & $\begin{array}{l}\text { Higher-level } \\
\text { thinking skills }\end{array}$ & $\begin{array}{l}\text { Complex } \\
\text { thinking skills }\end{array}$ & $\begin{array}{l}\text { Thinking about } \\
\text { thinking }\end{array}$ \\
\hline Interpreting & Analyzing claims & Evaluating arguments & Metacognition \\
\hline $\begin{array}{l}\text { Identifying } \\
\text { assumptions }\end{array}$ & Synthesizing claims & Reasoning verbally & Self-regulation \\
\cline { 1 - 2 } $\begin{array}{l}\text { Asking questions for } \\
\text { clarification }\end{array}$ & Predicting & Inference making & \\
\cline { 2 - 3 } & & Problem solving & \\
\hline
\end{tabular}


reasoning, and so on; and (2) critical thinking is judgment formation, is a pervasive and important one. However as we shall see, despite its importance, when applied to the higher education context (as opposed to a philosophical context) critical thinking is defined far too narrowly.

\section{Propensity Elements to Critical Thinking}

A very different, but no less important, way to think of critical thinking is not just in terms of cognitive elements such as argumentation and reflective thinking, but also in terms of propensity (i.e., an inclination or tendency to behave in a certain way). I shall look at propensity elements in this section.

\section{Critical Thinking as Dispositions (The "Skills-Plus-Dispositions" View)}

One such propensity is the notion of a critical thinking disposition (Facione et al., 1995). It has long been recognized that the ability to think critically is very different from the attitude or disposition to do so (Ennis, 1985b; Facione, 1990), and this too needs to be considered in any attempt to define critical thinking. Dispositions have been described as 'at least half the battle of good thinking, and arguably more' (Perkins, Jay, \& Tishman, 1992, p. 9).

Dispositions are sometimes defined as a "cast or habit of the mind" or "frame of mind" which is necessary for exercising critical thinking. Dispositions are not arguments or judgments, but affective states. They include critical thinking attitudes and a sense of psychological readiness of the human being to be critical. They are equivalent to what Passmore once called a 'critical spirit' (Passmore, 1967, p. 25), and have been defined as a constellation of attitudes, intellectual virtues, and habits of mind (Facione et al., 1995). They are internal motivations to 'act toward or respond to persons, events, or circumstances in habitual, yet potentially malleable ways' (Facione, 2000, p. 64). While not themselves skills or judgmental abilities, dispositions to think critically are seen by some to be a precursor to doing any critical thinking at all.

The notion of a disposition can be traced back to the work of the philosopher Gilbert Ryle who asserted that possession of a dispositional property was 'not to be in a particular state, or to undergo a particular change; it is to be bound or liable to be in a particular state' (Ryle, 1963). His classic example is glass which has a disposition to break even if it is not broken into pieces at a given moment. However, unlike glass, critical thinking is a reflective capacity, and is not automatic. It is the reflective capacity that qualifies a disposition as being a thinking disposition (Ennis, 1994; Tishman and Andrade, nd, p. 2). Dispositions, it should be noted, are different from skills or abilities - though obviously related to them-insofar as 
a person might not be disposed to use their skills or abilities even if they possess them (a talented pianist might not be disposed to exercise her skill by playing, for example).

Researchers have identified the following dispositions as most important for critical thinking:

- respect for alternative viewpoints (Bailin et al., 1999; Facione, 1990);

- inquisitiveness (Bailin et al., 1999; Facione, 1990, 2000);

- open-mindedness (Bailin et al., 1999; Ennis, 1985b; Facione, 1990, 2000; Halpern, 1998); fair-mindedness (Bailin et al., 1999; Facione, 1990);

- the propensity or willingness to seek or be guided by reason (Bailin et al., 1999; Ennis, 1985b; Paul, 1992b);

- a desire to be well-informed (Ennis, 1985b; Facione, 1990).

- tentativeness, skepticism, tolerance of ambiguity, and appreciation of individual differences (Halonen, 1995).

- seeing both sides of an issue (Willingham, 2007). (The latter is not exactly the same as tolerance of ambiguity; and this, arguably, could have a cognitive element as well.)

- Paul (1992a) identified a list that includes intellectual humility, intellectual courage, integrity, empathy, perseverance.

Some theorists, according to Facione, consider holding ethical standards to be an important critical disposition, on the grounds that 'a defense attorney using critical thinking abilities and dispositions to get her guilt client acquitted would not be a critical thinker' (Facione, 1990; Halonen, 1995; Lai, 2011, p. 12). This seems plausible, and most researchers would concur with this assessment.

\section{How Many Dispositions Are There?}

The number of dispositions that are stated to exist varies widely. Ennis, for example, has distinguished between three critical thinking dispositions, and fifteen separate critical thinking abilities (Ennis, 2011); Perkins, Jay and Tishman, by contrast, identify five dispositions. Some theorists also identify an overarching thinking disposition, identified by some as mindfulness (Langer, 1989), fairmindedness (Paul, 1990), critical-spiritedness (Siegel, 1988), or just an overarching disposition to think critically (Facione \& Facione, 1992). By the latter, it is meant that, not only should a person demonstrate the capacity (the cognitive skills) to seek reasons, truth, and evidence and so on-but they should also exhibit the drive or tendency to do so (Ennis, 1987, 1996). This drive or tendency is a critical thinking disposition. For Ennis, the critical thinking disposition is what animates or gives rise to the critical thinking skills discussed earlier.

Some scholars have gone to a great deal of trouble to provide extensive compendia of such dispositions (Facione \& Facione, 1992). But the role these dispositions play in relation to the cognitive skills of critical thinking remain in dispute. Some scholars, for example, have argued that a critical thinking disposition 
is not what animates or gives rise to the cognitive skills of critical thinking (as Ennis claims), but more a deep-seated character attribute. Siegel, for example, argues that Ennis fails to distinguish between the critical thinker as a person and their way of living from the critical thinking skills he or she exhibits. The former, according to Siegel (echoing Passmore) is a matter of "critical spirit" (Siegel, 1988).

Similarly, Paul distinguishes between critical thinking in the "weak" sense, and critical thinking in the "strong" sense (Paul, 1993). The former consists of the skills and dispositions already discussed; the latter consists of the examined life in which skills and dispositions have been incorporated as part of one's deepseated personality and moral sense-in short, one's character. This distinction shall become important for us later as it highlights the importance of the relationship of critical thinking to personality, consciousness and one's moral sense, i.e., one's actions and behaviours in terms of relating to others. This, in turn, is less a function of, I have called, the individual dimension of critical thinking, and more a function of the socio-cultural dimension. In terms I shall refer to later, this is, I feel, an axis dispute about critical thinking, not a dispute about substance, i.e., it is a matter of where, on my model of critical thinking, one locates one's interest in critical thinking (and on which axis).

For now, it is probably less important to provide an authoritative list of dispositions, and to form an opinion on the role of dispositions in relation to skills, but to merely acknowledge that scholarly work is ongoing in this area and dispositions are an essential part of critical thinking research.

\section{A Taxonomy of Critical Thinking Dispositions}

To sum up this section: critical thinking dispositions might be broadly categorized as falling under (1) dispositions arising in relation to the self, (2) dispositions arising in relation to others, and (3) dispositions arising in relation to the world. Again, it might be debated which category a disposition belongs to (and some might belong to more than one) but it is fairly clear that there are at least three dispositional orientations (Table 2.2).

There are other ways of categorizing the dispositions. Another way of creating a taxonomy of dispositions is to divide them, as does Facione (and the authors of the Delphi report), into two categories: approaches to life and living in general, approaches to specific issues/questions or problems (Facione, 1990, p. 13). Unlike Facione, however, I suggest a forth category, that can be added to the schema given above, namely, "other", for dispositions that do not easily fit into one or other of the earlier categories (for example, "mindfulness", "critical spiritedness", etc.).

Again, like the critical thinking skills and abilities, an attempt has been made by the present author to plot the various dispositions proffered by various authors over the years on the topic of critical thinking-from Dewey's work onwards-into a table and to cross-tabulate the results. This table is available from the present author upon request. 
Table 2.2 Critical thinking dispositions

\begin{tabular}{l|l|l|l}
\hline $\begin{array}{l}\text { Dispositions arising } \\
\text { in relation to self }\end{array}$ & $\begin{array}{l}\text { Dispositions arising } \\
\text { in relation to others }\end{array}$ & $\begin{array}{l}\text { Dispositions arising } \\
\text { in relation to world }\end{array}$ & Other \\
\cline { 1 - 3 } $\begin{array}{l}\text { Desire to be } \\
\text { well-informed }\end{array}$ & $\begin{array}{l}\text { Respect for } \\
\text { alternative viewpoints }\end{array}$ & Interest & Mindfulness \\
\cline { 1 - 2 } $\begin{array}{l}\text { Willingness to seek or } \\
\text { be guided by reason }\end{array}$ & Open-mindedness & $\begin{array}{l}\text { Seeing both sides of } \\
\text { an issue }\end{array}$ & \\
\cline { 1 - 1 } Tentativeness & Fair-mindedness & & \\
\cline { 1 - 1 } Tolerance of ambiguity & $\begin{array}{l}\text { Appreciation of } \\
\text { individual differences }\end{array}$ & & \\
\cline { 1 - 1 } Intellectual humility & Skepticism & \\
\cline { 1 - 1 } Intellectual courage & & & \\
\cline { 1 - 1 } Integrity & & & \\
\cline { 1 - 1 } Empathy & & & \\
\cline { 1 - 1 } Perseverance & & \\
\cline { 1 - 1 } $\begin{array}{l}\text { Holding ethical } \\
\text { standards }\end{array}$ & & & \\
\hline
\end{tabular}

A preliminary network analysis of dispositions is provided below (Fig. 2.2). The larger circles indicate the number of dispositions noted, and the cross-linkages indicate the level of agreement between authors. On this analysis, considerable agreement exists in the dispositions suggested by Ennis, the authors of the Delphi Report, and the work of Halpern, Bailin and Facione. A number of "outlier" dispositions exist as isolated nodes (e.g., by Halonen, Siegel, Jay and Tishman, Noddings, and others), which seem to have no corresponding agreement with other authors. An account of dispositions along these lines helps to establish, by general agreement, which dispositions are more important by means of democratic consensus. However, it does not establish that "outlier" dispositions are wrong or ill-conceived.

Unlike the list of cognitive elements to critical thinking discussed earlier, there is a great deal of diversity of opinion as to what constitutes critical thinking dispositions and how they should be configured.

\section{What Is the Relationship Between Dispositions?}

Advancing what they call, a "triadic account" of critical thinking dispositions, Perkins, Jay and Tishman identify the following dispositions: the disposition to be being broad and adventurous; the disposition toward wondering, problem-finding and investigating; the disposition to build explanations and understandings; the disposition to make plans and be strategic; the disposition to be intellectually careful; the disposition to seek and evaluate reasons; the disposition to be metacognitive (thereby identifying metacognition as not a thinking skill, per se, but a disposition to be so inclined). They also identify three components or elements to a disposition: sensitivity (a perception of appropriateness); inclination (the felt impetus toward 


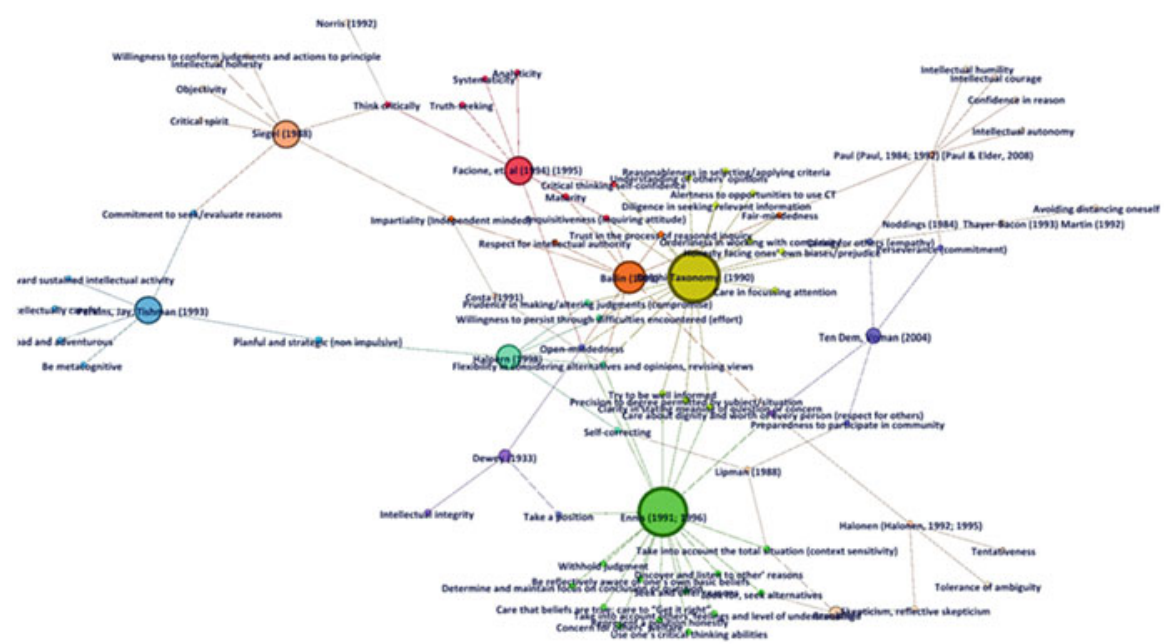

Fig. 2.2 Network analysis of dispositions [NB: This is a work-in-progress by the present author]

a behaviour), and ability (a basic capacity to follow-through with a behaviour) (Perkins et al., 1992). Some empirical studies have attempted to isolate which are most important, and there is ongoing research into this area (Facione et al., 1995; Ip et al., 2000).

The general point here, however, is this: there is clearly a difference between demonstrating cognitive skills in critical thinking (qua argumentation and judgments), and being critically disposed toward someone or something. In keeping with the analogy mentioned earlier, a lawyer might demonstrate impressive skills in argumentation and reflective thinking (judgments). For example, he or she could marshal clever arguments in order to acquit his or her client. Yet they might not be critically disposed towards their client, nor necessarily see his or her case as something that is important, interesting or worthwhile. Again, such a case would scarcely be a model of critical thinking.

Without critical thinking dispositions, it seems, any adequate understanding of critical thinking is not complete. And yet, broadening critical thinking beyond the confines of critical thinking-as-argumentation (critical thinking as "logicality") to include dispositions-i.e., moving from a "skills-based" view to a "skills-plusdispositions"-based view-also holds the prospect for extending the notion of critical thinking even further. This is what I shall do in Part 2.

\section{Critical Thinking as a Composite of Skills and Attitudes}

Critical thinking has naturally been seen in terms of a composite of skills, knowledge and attitudes too-including argumentational, reflective and affective features (Boostrum, 1994; Brookfield, 1987; Facione, 1990; Kurfiss, 1988; McPeck, 1981; 
Paul, 1981; Siegel, 1988, 1991; Watson \& Glaser, 2008). Most theorists hold a composite account. The composite view includes both the cognitive and propensity elements discussed above. While the ability to argue and make inferences, to reflect and make judgments, and be critically disposed is all important, it is also crucial to recognize that each of these do not occur in isolation. In the case of McPeck, critical thinking involves a disposition and a skill, and 'one must develop the disposition to use those skills' (McPeck, 1981, p. 3), hence, his definition of critical thinking as 'a propensity [disposition] and skill to engage in an activity with reflective skepticism' (McPeck, p. 8). Similarly, Kurfiss claims that argumentation is the "vehicle by which justification [of beliefs] is offered' (Kurfiss, 1988, p. 13).

How the cognitive and propensity elements relate to each other in any definition of critical thinking is subject to much discussion. Facione, et al., for example, postulate an interactionist hypothesis where "the disposition toward critical thinking reinforces critical thinking skills and that success with critical thinking skills reinforces the disposition' (Facione et al., 1995, p. 17). They also claim that cognitive skills and dispositions are "mutually reinforced" and should be explicitly taught and modeled together (Facione et al., p. 4). These are complex issues, the details of which will not concern us here.

\section{Critical Thinking as Emotions}

Another propensity element that is sometimes overlooked in discussions about critical thinking is the emotions. Brookfield has noted that critical thinking is as much an emotional concept, as a cognitive one (Brookfield, 1987). Emotions are a part of our propensity toward critical thinking. He argued that both positive and negative emotions can lead to critical thinking; such as, for example, when an element of surprise leads to a state of disequilibrium, and thence to critical thinking that tends toward overcoming the state of uncertainty. This is as important to critical thinking as the cognitive and affective elements identified by others. According to Brookfield, 'joy, release, relief, and exhilaration' allows critical thinkers to 'break through to new ways of looking at our ... world' (Brookfield, p. 7). The importance of emotions to critical thinking has been noted by others (Halonen, 1986). I include several dispositions in our earlier table which might be thought of as emotion-based dispositions.

\section{Critical Thinking as Action}

In a wider sense, of course, adopting a stance of critical action is also very important. It is not enough, for example, to be critically disposed and to have a reasonable and rational inclination "to believe or do" something, it is also important to act accordingly. This too is part of what we mean by "critical thinking". Being actively critical of government actions and political decision-making is a clear example of this. This might include - to take a topical example-attitudinal or 
physical rebellion against the use of tax-payers money to subsidize errant corporate greed (e.g., the under-writing of the US banking system following the recent economic crisis), or actions in relation to topical issues such as globalization (witness the recent anti-government protests around the world) or protests at government inaction in relation to the challenge of climate change. To take a recent example, it could consist of the protests against military coups (e.g., in Egypt). How can this latter sense of critical thinking be distinguished and reconciled with the cognitive and propensity elements of critical thinking given earlier?

Definitions of critical thinking as they are applied in the discipline of philosophy, or the philosophy of education, and as they are applied in higher education, seem to diverge at this point. However, they remain consistent in any comprehensive interpretation of "critical thinking" as we shall see (see "A model of critical thinking in higher education").

To conclude this section: As it has been traditionally defined, by Ennis, Paul, McPeck, Lipman, and others in the critical thinking movement, critical thinking has been seen largely in terms of cognitive elements, e.g., as 'reflective and reasonable thinking that is focused on deciding what to believe or do'. However, this definition is remiss by not including in its scope any sense of actual or potential action. And, as noted earlier, higher education is, amongst other things, a defining feature of how we live our later lives as agents of change. Higher education provides us, as students, a basis upon which we not only make judgments, and construct and evaluate arguments, but also a basis upon which we live in the world as practical beings (not merely "reflecting" beings). Higher education forces us to confront the world. It educates us into participating in the world as an engaged citizen. While philosophers of education have their own justifiable reasons for narrowing the scope of critical thinking to cognitive and affective factors-and this narrowing has important advantages in terms of shedding light on the nature of critical thinking - it is essential that critical thinking is defined more broadly for a higher education context. This definition-for a higher education context (as opposed to a philosophical context)—would include what is sometimes called "criticality", “critical citizenship" and "critical pedagogy" (see Part 2).

\section{A Framework of Critical Thinking Skills and Propensities}

Before turning to this, however, I should place the various features of critical thinking thus far described into a conceptual framework. Fortunately, others have already done this work. The following diagram has been adapted from Halonen (1995), and isolates the two main elements of critical thinking-i.e., both cognitive and propensity elements - along with the previously outlined features of metacognition, emotions, a selection of various cognitive attitudes or dispositions, and a state of personal physiological readiness (Fig. 2.3).

On this model, the latter (physiological readiness of the person, their critical dispositions and attitudes, and their emotions) all modulate and have the capacity 


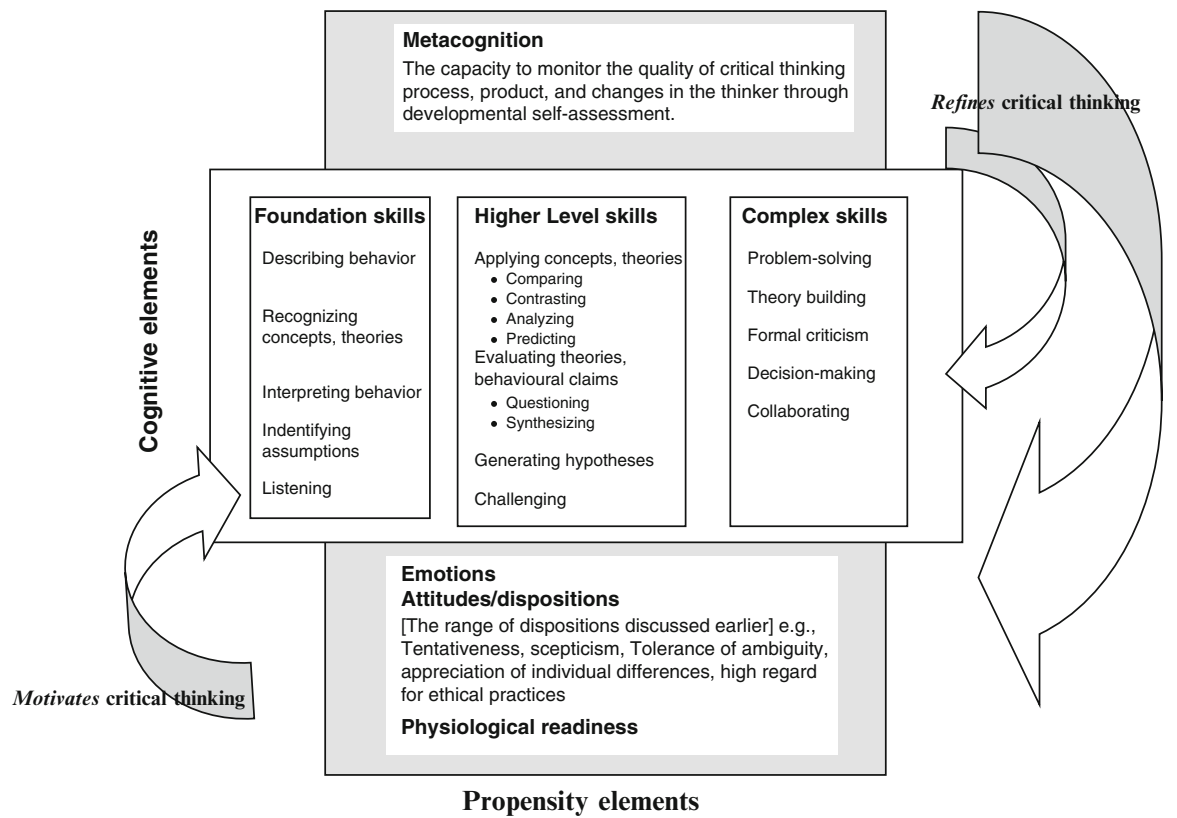

Fig. 2.3 The cognitive and propensity influences on critical thinking (Adapted from Halonen, 1995)

to motivate and influence cognitive critical thinking skills. As previously discussed, the role of metacognition is to refine and monitor critical thinking in both cognitive and affective forms. Halonen helpfully identifies three types of cognitive critical thinking skills as we have done, i.e., "foundation", "higher level" and "complex" in the diagram below. Using the list of Delphi skills and abilities provided earlier, these are roughly equivalent to interpretation and descriptive skills ("foundation"), explanation and evaluation skills ("higher level") and analysis and inference ("complex") skills respectively. Again, the tripartite distinction in skill level is indicative that some cognitive capacities are more complex-and require more skill-than others.

In the online tables referred to earlier, I provide an extensive list of (a) the skills of critical thinking and (b) the critical thinking dispositions as noted by several authors in the field. The diagram above sums all of these in one framework (Fig. 2.3).

\section{Dimensions of Criticality: An Axis Diagram}

Another way of representing these concerns in a more general way is by using an axis diagram. I begin to build the components of this diagram below, and will add to the diagram in Part 2. The first stage of the diagram indicates the general concerns of the critical thinking movement just outlined (the shaded block) occurring along what might be called an individual "axis of criticality" (the "Y" axis). The term 
"criticality" is used here deliberately as a neutral word, unlike historical loaded uses of the phrase "critical thinking". The latter has become accreted with various meanings over time, and has become hard to define as a result. "Criticality", happily, implies no particular account of critical thinking or theoretical emphasis. As we shall see in the next section, this word is becoming currency among higher education academics, and others. As we also shall see later-when I come to expand on this axis diagram - this axis will be important, as other dimensions of criticality have a quite different focus and lie on a different axes. But I submit that all, in their own way, inform our understanding of critical thinking in higher education.

The diagram below represents the critical thinking movement which I have just outlined in some detail (Fig. 2.4). This movement is largely concerned with individual qualities, i.e., cognitive elements or "inner" skills (argumentational skills, skills in thinking) and propensity or character attributes of the person (dispositions and abilities). These are inclusive of all the skills and attributes mentioned in the diagram provided above (i.e., foundation, higher-level, complex, metacognitive skills, as well as the much discussed critical thinking abilities and dispositions). These skills and dispositions are represented by separate lines radiating out from the bottom of the $\mathrm{Y}$ axis. This account of criticality is what we might call "critical thinking proper" or critical thinking in its traditional senses. This represents the concerns of the critical thinking movement. The " $\mathrm{X}$ " axis, the "socio-cultural axis of criticality', will be expanded on in Part 2 of the paper.

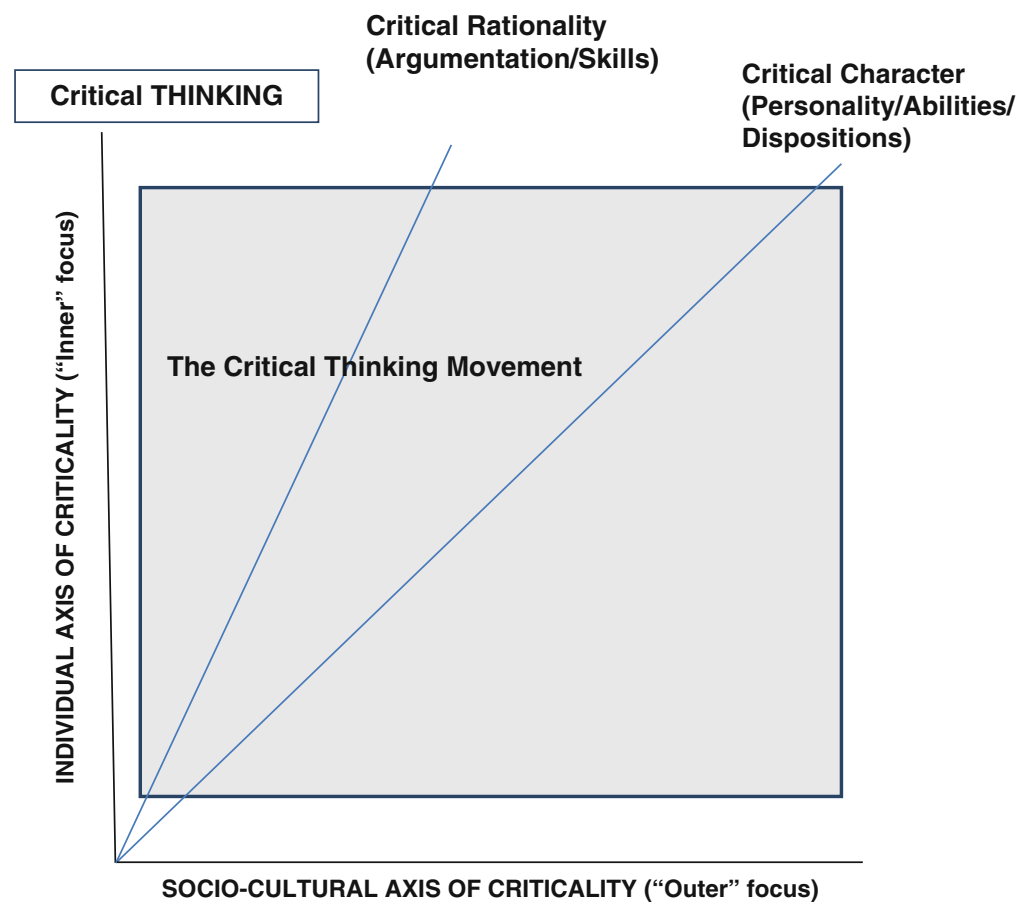

Fig. 2.4 Axis diagram: the critical thinking movement 


\section{Conclusion}

Part 1 of this paper outlined the philosophical account of critical thinking in some detail, including the critical thinking movement and its emphasis on critical thinking as skills, judgments and dispositions. An inclusive framework for cognitive and propensity elements of critical thinking was provided. It was suggested that these aspects of critical thinking can be seen as dimensions of criticality. Moreover, they can be considered as "axes" in an overarching model of critical thinking in higher education. In Part 2, I develop the model further by turning to critical thinking as it is discussed, not amongst philosophers, but amongst educators; in particular, educators and professionals in Higher Education.

\section{Part 2: The Socio-cultural Axis}

Ron Barnett has defined critical thinking in terms of taking a "critical stance". He claims: 'Critical persons are more than just critical thinkers. They are able to engage with the world and with themselves as with knowledge' (Barnett, 1997, p. 1). Elsewhere, he refers to a critical stance as a disposition, as 'the ability to size up the world in its different manifestations and the capacity to respond in different ways. ... a willingness to evaluate the world, howsoever it appears. A disposition, after all, is deep-seated. It suggests that we are in the presence of a person of a certain kind. The critical spirit, therefore, involves persons fully; it involves and takes over their being' (Barnett, p. 87).

This might seem, on the surface, to be vague and unhelpful as a wider definition of critical thinking, and seems to conflate skills and dispositions (see Part 1). However, the definition requires some unpacking in the context not of "critical thinking" per se, but of "criticality". This leads us to yet another account of critical thinking to those previously discussed; one which broadens the notion of critical thinking even further from both the "skills-based" view and the "skills-plusdispositions" view. This is the "skills-plus-dispositions-plus-actions" view.

This part of the paper will outline this and two other accounts of critical thinking in Higher Education before articulating a formal model of critical thinking in higher education.

\section{Critical Thinking as "Criticality" (The "Skills-Plus-Dispositions-Plus-Actions" View)}

The interpretation of "critical thinking" used amongst higher education scholars is sometimes expressed in terms of the term criticality. "Criticality" is a term of fairly recent origin; a word deliberately distinct from the traditional expression 
"critical thinking", which - after half a century of debate and discussion-is now a loaded and over-used. The term "criticality", by contrast, attempts to provide an ambit perspective of the concept of critical thinking incorporating argument, judgment/reflection and critical action. It also extends beyond the individual to the individual's participation in the world, i.e., in the form of responsible citizenship. This is a concept of critical thinking involving students reflecting on their knowledge and simultaneously developing powers of critical thinking, critical self-reflection and critical action-and thereby developing (as a result) critical being (Barnett, 1997, 2004; Johnston, Ford, Mitchell, \& Myles, 2011). "Criticality", not unlike, "critical thinking" is, in some quarters, gaining its own scholarly industry.

"Criticality", although not an established definition of critical thinking in use by the critical thinking community, and rarely used at all by philosophers (although see Burbules \& Berk, 1999; Paul \& Elder, 2001) nonetheless constitutes a unique sense of "critical thinking" increasingly in use and widely discussed in higher education circles (see, for example, the number of publications arising from "The Criticality Project") (The Criticality Project, 2013). It is important therefore that it is explained clearly.

\section{What Is "Criticality"?}

What is "criticality"? Broadly speaking, criticality comprises—and is a composite of-three things: thinking, reflecting and acting. In emphasizing "action" in addition to thinking (in the form of argumentation and reflective judgment), "criticality" might thus be seen, and conceived of in relation to established definitions of critical thinking as trait: the exercise of which is critical thinking as customarily defined, say, as 'reasonable reflective thinking focused on deciding what to be or do' (Ennis, 1985b, p. 45). That is, while a critical thinker can be disposed to think critically, in practice this assumes that he or she exhibits a trait to do so, and to act accordingly. This trait is criticality. "Criticality" requires that one be moved to do something (Burbules \& Berk, 1999, p. 52). Ennis himself has acknowledged that this concept is missing in his well-known definition of critical thinking (Ennis, pers. comm. 2012) While skills and dispositions are crucial for critical thinking, they are not sufficient unless action is added. To adapt a famous line from Kant: critical thinking without skills is empty; criticality without action is blind.

\section{An Example of "Criticality"}

The concept of criticality as a trait-as composite of critical thinking, critical reflection and critical action-has been made concrete by the use of a famous photograph as a frontispiece of Barnett's book Higher Education: A Critical Business (1997). The photograph depicts a student in front of a line of tanks in Tiananmen Square in 1989. Most people have seen this photograph; indeed, it is 
one of the defining photographs of the latter part of the twentieth century. How does the photograph demonstrate critical thinking as "criticality"?

Using this photograph, Barnett implies that higher education should be (if not always in practice) an educational process involving a composite of thinking, reflecting and action. "Critical thinking", in the established cognitive sense proposed by philosophers such as Ennis, Siegel, Lipman, McPeck and others, is an important, but by itself inadequate, as a way of capturing what higher education can be at its best. Barnett describes this established sense of critical thinking as 'thinking without a critical edge' (Barnett, 1997, p. 17). Higher education can potentially do more than teach students how to demonstrate (for example) 'reasonable reflective thinking focused on deciding what to believe or do' i.e., critical thinking as skills and judgments. It can also prompt students to take action, and to demonstrate a socio-political stridency against established norms or practices with which they are confronted. This, it is argued, is more than what is offered by the critical thinking movement in relation to skills in critical thinking; it is tantamount to the development of critical beings.

This is most dramatically demonstrated in the photograph of the student protester in China, who was, against all odds, acting as a critical being. Critical thinking, in this very broad sense, qua criticality, is an emerging concept in higher education scholarship. It expresses the yearning that higher education-in its most developed form at least - functions to educate citizen to "do" something critically as well as "be" a critical thinker, and not merely to "reflect" or "judge" critically (still less merely to "argue" critically). In embracing criticality, higher education attempts to embrace a higher-order sense of "critical thinking".

This is a sense of "critical thinking" that—while not inconsistent with established definitions - strives to extend them from the philosophical sphere of cognitive skills and dispositions, to the sphere of practical application-i.e., critical thinking as a trait. It extends beyond the individual and his or her cognitive states and dispositions to the individual's participation in society as a critically-engaged citizen-in-theworld. Note that it also includes a moral and ethical dimension to critical thinking. After all, a critical thinker does more than reason; they also act ethically on the basis of their reasoned judgments. The Chinese student in front of the tank was doing something that he thought was morally right. Moreover, it was moral rightness that was beyond deliberate weighing of pros and cons to arrive at a decision; in fact, his action was trans-critical. Had the student rationally considered for a moment what he was about to do, he would almost certainly had not done it. This action could be considered an instinctive action in response to the perceived "wrongness" of the situation. I shall return to this towards the end of the paper.

In developing this argument for the criticality dimension, Barnett claims that critical thinking, critical reflection, and critical action could be thought of as three interlocking circles in the form of a Venn diagram (see below). It is important, according to Barnett, that they be regarded as interlocking-but not as entirely congruent with each other; otherwise, the space for each of them to work (including "critical thinking" in the cognitive sense) would be lost (Fig. 2.5). 
Fig. 2.5 The intersection between critical reason, critical self-reflection and critical action (Barnett, 1997, p. 105)

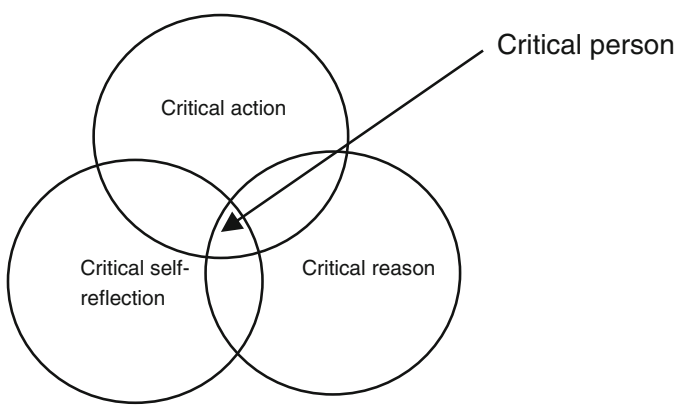

"Thinking" critically, "reflecting" critically, and "acting" critically (and being "critically disposed") are subtlety different concepts, and require a different emphasis; and one can be a "critical thinker" in all of these ways jointly, or in each of these ways separately. Just as we saw in Part 1 that a lawyer could demonstrate critical thinking qua argumentation and reflection without having a critical disposition, so could a lawyer demonstrate cognitive skills in critical thinking and reflecting, and critical dispositions, without the necessary and appropriate commitment to action. That is, he or she might be disposed to think critically about their client, but not be willing to do anything about it. Without action, however, it is not clear that it would be a wholly satisfactory case of critical thinking. Just as the importance of skills and dispositions was an important insight of the critical thinking movement, the centrality of action is the fundamental insight provided by "criticality" theorists. In Part 1 we saw the importance placed on critical thinking in terms of skills and dispositions. Now we see the importance of including critical action.

The multi-faceted nature of critical thinking is, I suspect, part of the reason that the concept of critical thinking is confusing, and hard to define. Perhaps this is why - in the context of the discipline of Higher Education-critical thinking is often seen as a "wicked" competency, that "cannot be precisely defined, takes on different shapes in different contexts, and is likely to keep on developing' (Knight, 2007 , p. 1). Another reason is that "critical thinking" is used as a concept in very different ways, and for different purposes. Indeed, even within the sphere of critical thinking in higher education, the term is used differently by philosophers and higher education professionals, as we have seen.

The respective concerns of educational philosophers and higher education scholars in relation to the topic of critical thinking are different, and have a quite different explanatory purpose. The work of Ennis, Paul, McPeck and others aims to identify the philosophical elements of what a critical thinker is or should be; the work of Barnett - and those interested in criticality - aims to identify what a critical thinker does and can become. In turn, the implications for higher education on producing critical beings - prepared to act and critique social norms - also holds out a promise for what higher education can be-which, demonstrably, given the "corporate" nature of the university, it is not at present (Cowden \& Singh, 2013). Together, as we shall see, these separate and complimentary accounts provide a potentially insightful view of the nature and concerns of critical thinking in higher education. 


\section{Educating for Criticality}

"Criticality" then is a wider concept than "critical thinking", as it is customarily defined by educational philosophers. To some extent it subsumes it. One outcome of this wider concept being taken up, of course, is that it suggests a wider set of responsibilities on higher education professionals, i.e., teachers and academics, than that of (simply) imparting skills in argumentation, or developing in students a capacity for rational "reflection" or decision-making, or cultivating critical thinking dispositions. Educating for criticality — as opposed to education merely for critical thinking - holds out a sense that higher education can become (more) a process of radical development than merely a process of education; it captures a sense of enabling students to reach a level of what Barnett calls "transformatory critique" (i.e., to live and breathe as a critical thinker; to become an exemplar of what it means to be a "critical being"). (see Barnett, 1997, pp. 103-115)

Regardless of the various terminology and definitions used throughout history, "critical thinking" - however it is defined—is recognized by all as vitally important in terms of developing the skills necessary for individuals to appropriately understand, reflect on, and engage with important issues. This, it is hoped, leads towards the ultimate end of developing and enabling effective and responsible citizenship, i.e., to become an upstanding, engaged, and fully participating, and flourishing member of society (Ten Dam \& Volman, 2004). As noted in our discussion of the Chinese student, educating for criticality, to produce a critical being, not merely a critical thinker, also has a moral and ethical dimension. In educating for critical citizens, we take it for granted that critical citizens will behave justly, will respond to situations morally, and will act responsibly (albeit critically, in reaction to perceived wrong-doings). This, criticality theorists argue, is as much a part of critical thinking — and a consequence of critical thinking — as argumentation, dispositions and attributes. Indeed, it might be seen as the preeminent role and function of higher education. I return to critical being later.

\section{The Axis Diagram Revisited}

We can now see the place of the "criticality" dimension in our axis diagram and its relationship to the critical thinking movement. The criticality dimension is represented below as a shaded block in relation to the concerns of the critical thinking movement (CTM). For simplicity, I shall call this new dimension "The criticality movement" (CM). However, this is an attenuated sense of the word "movement". The criticality movement, as I am calling it, is less a formal movement—understood as a wide-spread "call to action" - as a set of concerns held by a number of higher education academics in reaction to traditional accounts of critical thinking (i.e., the CTM). It could be considered part of "third wave" theorizing (Paul, 2011). Nonetheless, it is helpful to consider it a movement, albeit a movement with a much smaller, through growing, influence. 
The concerns of the criticality movement arise in reaction to the narrow emphasis of previous accounts of critical thinking. These previous accounts view critical thinking in terms of individual skills, dispositions and abilities. While proponents of the criticality dimension certainly do not eschew these important individual facets of critical thinking entirely (indeed, they endorse their importance), the "criticality" perspective adds something new. It adds the dimension of action to the mix. This is represented by the addition of the social-cultural axis (the " $\mathrm{X}$ " axis) of critical thinking shown below, and in what I note here as "Critical Doing".

However, given our earlier discussion, there is more to it than action. Unlike the views of critical thinking as adumbrated by proponents of the critical thinking movement—what I might call—Critical Thinking proper (e.g., the work of Ennis, McPeck, Siegel, Paul and others), for the criticality theorists the ethical dimension is also important to critical thinking. Ethical decisions are, of course, usually (if not always) accompanied by ethical actions. This is represented by the critical virtue axis below. Note in the diagram that the CTM, with few exceptions, does not include the action and morality dimension in their considerations of critical thinking. Therefore these axes do not intersect with the CTM, though they do intersect with the CM.

It is important to stress that those sympathetic to criticality do not disregard argumentation skills, and critical thinking dispositions as in any way unimportant, dispensable, misleading or redundant. These, they agree, are central features of critical thinking. Indeed, the shaded bloc representing the criticality account below overlaps these axes of critical thinking in the diagram. However, "criticality", as they understand it, comprises far more than critical thinking, it also involves doing. This, they feel, is under-reported and not acknowledged as it should be. Unlike the CTM, the $\mathrm{CM}$ includes critical actions and critical virtue as additional facets of criticality. These dimensions too must be included in any adequate account of critical thinking as it applies to higher education. I shall revisit the axis diagram below yet again following a brief discussion of another facet of critical thinking in higher education, namely, critical pedagogy (Fig. 2.6).

\section{Critical Thinking as Critical Pedagogy (The "Skills-Plus-Dispositions-Plus-Actions-Plus-Social Relations" View)}

Critical pedagogy is defined as the use of higher education to overcome and "unlearn" the social conditions that restrict and limit human freedom. According to one of its major proponents, it is 'an educational movement, guided by passion and principle, to help students develop consciousness of freedom, recognize authoritarian tendencies, and connect knowledge to power, and the ability to take constructive action' especially in relation to education and society at large (Giroux, 2010). 


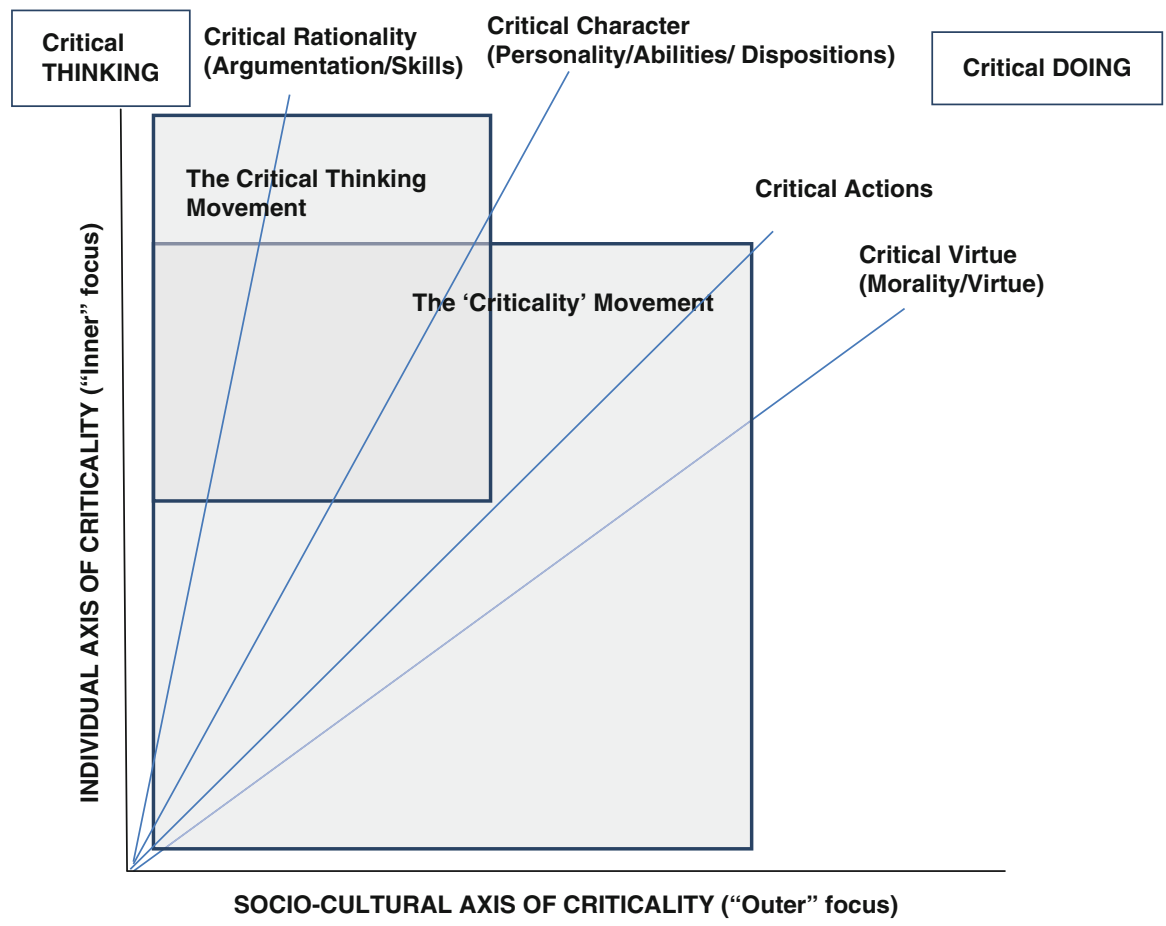

Fig. 2.6 Axis diagram: the critical thinking and "Criticality" movements

Like the approach taken by Barnett, Johnston, and others in their account of "criticality", critical pedagogy takes the view that critical thinking needs to be broadened beyond skills and dispositions. It sees the account of critical thinking as comprising skills-plus-dispositions as a view very much concerned with the individual. Like the adherents of the criticality approach, however, the critical pedagogues include the importance of action. However, unlike adherents of the criticality approach, they consider social relations-not merely actions- to be a vital factor for critical thinking. This broadens the notion of critical thinking even further than any of the views previously discussed. This broadening, depending on one's perspective, either illuminates or confuses the discussion about the nature of critical thinking as we shall see.

This is clearly an extension of Barnett's account of the radically transformed student; indeed, it extends radical educational transformation to society at large. The critical pedagogues see critical thinking to be not about argument analysis, nor dispositions, nor individual actions (although these too are important). They see critical thinking to be principally about 'the critique of lived social and political realities to allow greater freedom of thought and action' (Kaplan, 1991, p. 362). From Marxism, they borrow the concept of political and economic oppression, and the need to liberate human freedom; from psychoanalysis, they take the importance 
of the decoding of cultural forms of knowledge; from phenomenology, the imbibe the idea of "lived experience" (Kaplan, 1991). This concatenation of theories and ideas results in a view of critical thinking that is a further extension and corrective to earlier accounts described in this paper.

The key theorists in this area are Freire (1972), McLaren and Hammer (1989) and Giroux (1994, 2005). In an illuminating article by Burbules and Berk (1999), the following distinctions are made between the critical thinking movement (incorporating the "skills-based" view of critical thinking and the "skills-plus-dispositions" view), and the critical pedagogy movement. I will overview these distinctions before returning to my developing model.

\section{The Aim of Critical Thinking}

The critical thinking movement begins from a view of seeing the critical person as a 'critical consumer of information' (Burbules \& Berk, 1999, p. 48). This involves using his or her rationality to adjudicate between truth and falsehood, identify hasty generalisations, expose unreliable authority, distinguish between reliable and unreliable information, to carry out argument analysis, and so on. The aim of the movement is to create taxonomies of the skills and dispositions required to achieve the aim of being critical thinkers and to use and inculcate those skills and dispositions in teaching. This naturally emphasises the role that higher education can play in incorporating these skills, and cultivating these dispositions in the classroom. The aim of the critical thinking movement—at least during its first "wave"—was to put formal and informal logic at the service of pursuing clear and dispassionate thinking (Paul, 2011).

The critical pedagogy movement (CPM) begins from a very different starting point. The first-wave theorists took the adjective "critical" to mean "criticism" (i.e., pointing out weaknesses with a view to correcting some claim or argument). Their aim was putting logic at the service of clear thinking. The critical pedagogues, by contrast, took "critical" to mean "critique" (i.e., identifying other dimensions of meaning that might be missing or concealed behind some claim or argument) (Kaplan, 1991, p. 362). Their aim puts logic at the service of transforming undemocratic societies and inequitable power structures. Their aim is not simply educating for critical thinking, but educating for radical pedagogy. They see the critical person as a reactionary against the ideological hegemony of capitalism; a hegemony which foists conditions favourable to the maintenance of the capitalist system onto unwitting members of society. They see advertising, for example, as encouraging and fostering increased material consumption whilst simultaneously reinforcing the myth that large corporations are there to serve their customers, when they are, in fact, serving their own interests, and maximising profit, often at the expense of both customers and the social good (Burbules \& Berk, 1999, p. 50).

The critical pedagogy movement sees higher education, as it stands, as part of the entrenched capitalist ideology that reinforces and legitimizes these social conditions. This occurs in a number of ways, most obviously in "the banking 
concept of education" in which "education ... becomes an act of depositing, in which the students are the depositories, and the teacher is the depositor' (Freire, 1972, p. 363; Kaplan, 1991). On this account, the student is assumed to be both ignorant and a supplicant. It can also be seen in the emphasis of higher education in producing — not intellectually-challenged — but vocationally-trained workers readymade for a capitalist social system; i.e., pliable minions conforming to social expectations and meeting socio-political ends.

It can also be seen in the direction taken by the "corporate" university of the twenty-first century in viewing education as a marketable "product" and seeing students as "consumers" or "clients" The emphasis on "accountability" and renewed emphasis on testing in the contemporary higher education can also be seen as a feature of a consumer-driven model of the modern university. This has recently been disparagingly described as a "Sat-Nav" educational system: a commoditized system of exchange between universities and their "customers" that results in a failure of tertiary institutions to provide real intellectual challenges to students in a way which erodes institutional educational integrity (Cowden \& Singh, 2013).

The critical pedagogues are stridently opposed to such moves, and see critical thinking as a means of reacting to this direction in higher education today. They believe that the aim of education should, instead, be about turning students against the idea of being trained for the economic needs of large corporations. This can be achieved by making students and their teachers more reactionary-to create "critical intellectuals" (Giroux, 1988). This is clearly a very different, although no less important, sense of "critical thinking" than we have looked at to date.

This attitude toward the corporate university, i.e., its serving an entrenched capitalist, socio-political agenda, is no mere socialist paranoia on the part of the critical pedagogy movement. It is worth noting again that as recently as 2012, there was strident opposition to the teaching of critical thinking skills, and any other higher order thinking skills: "which focus on behaviour modification and have the purpose of challenging the students' fixed beliefs and undermining parental authority'. This opposition to critical thinking in the classroom was part of the Texas-based Republican party platform, an official policy that was widely condemned and quickly retracted (Cuban, 1984, p. 12; Morse, 2012; Strauss, 2012). So there is some basis for the critical pedagogy moment as being concerned about the existing political aims of higher education. They see it as already serving a fraught socio-political agenda. They would see the recent republican attack on critical thinking is evidence of it.

The critical pedagogy movement sees the role of higher education, not as reinforcing, but as dispelling these uncritical attitudes and questioning these assumptions. They see the role of higher education as working within higher educational institutions to identify and critique power inequities in society, the myths of opportunity in capitalist economies, and 'the way belief systems become internalized to the point where individuals and groups abandon the very aspiration to question or change their lot in life' (Burbules \& Berk, 1999, p. 50). "Thinking critically", for them, is not principally a matter of cultivating certain skills and dispositions, but recognizing, and critiquing, pedagogical relations in society that maintain the capitalist status quo. 


\section{Critical Thinking for Action}

Another difference between the critical thinking skills movement and the critical pedagogy movement is the commitment to action. I have already identified the importance of action in the previous section.

As we have seen, the authoritative definition of critical thinking widely adopted by many in the critical thinking movement assumes-but does not formalisea commitment to action. Ennis' definition of critical thinking as 'reasonable reflective thinking focused on deciding what to believe or do' assumes 'an overly direct connection between reasons and action', and that "believing" will lead unproblematically to "doing" (Burbules \& Berk, 1999, p. 52). We have seen that this point highlights strains within the critical thinking movement, and a launching point for the work of Barnett (1997) and his analysis of the tripartite account of critical thinking, critical reflection, and critical action.

Like Barnett, the critical pedagogy movement sees action as an intrinsic, not separable, aspect of critical thinking. However, they take critical action much further. They see action as important not merely for encouraging personal individual reaction to events before one, but as a justification for wholesale social and political change. As Burbules and Berk put it, for them: 'challenging thought and practice must occur together ... criticality requires praxis - both reflection and action, both interpretation and change ... Critical Pedagogy would never find it sufficient to reform the habits of thought of thinkers, however effectively, without challenging and transforming the institutions, ideologies, and relations that engender distorted, oppressed thinking in the first place - not an additional act beyond the pedagogical one, but an inseparable part of it' (Burbules \& Berk, 1999, p. 52).

\section{Teaching for a Critical Mindset}

Another difference between the two movements is this: The critical thinking movement sees the objective of teaching critical thinking skills and dispositions as conditions for fermenting a critical mindset among students as part of a general agenda for improving the aims of higher education. They see teaching critical thinking as allowing students to distinguish between truth and falsity; misleading and doctrinal information; and alerting them to fallacies of thought and flawed assumptions. They see critical thinking as an emancipatory practice of providing tools for students to "think for themselves" and "form their own conclusions".

The critical pedagogy movement, however, sees the teaching of critical thinking very differently. They see it as a way of alerting students to their indoctrination and their role in serving an entrenched capitalist political system. Moreover, they see the role of teaching critical thinking as alerting them to the social conditions that have led to this.

For the critical thinking movement, this is a flawed attitude. It amounts to taking for granted and prejudging the conclusions to an issue. It is itself equivalent to indoctrination. However, for the critical pedagogy movement, raising the issue of the 
social conditions of freedom is essential to critical thinking. "True" critical thinking, for them, involves liberation from an oppressive system as a condition of freedom of thought. As Burbules and Berk put it: 'Critical thinking's claim is, at heart, to teach how to think critically, not how to teach politically; for Critical Pedagogy, this is a false distinction ... self-emancipation is contingent upon social emancipation' (Burbules \& Berk, 1999, p. 55). In the words of the "Critical Pedagogy Collective" (echoing Dewey): 'Education is not preparation for life-education is life itself' (The Critical Pedagogy Collective, 2013).

\section{Critical Thinking as Conformity}

It will be clear by now that the aims of the critical thinking movement and the critical pedagogy movement are very different. They form different axes on our diagram as we shall see. These differences mean that the one movement sees the other in often hostile terms (Burbules \& Berk, 1999, pp. 53-54). However, I suggest that these hostilities amount to being axis disputes. They amount to seeing alternative perspectives of critical thinking from the vantage points very different from one's own. More on this later.

In not directly addressing political concerns, the proponent of critical pedagogy sees the objectives of the critical thinking movement as being evidence for (uncritical) conformity to a certain social system. In their view, by being politically and socially impartial, the critical thinking movement ignores one of the central reasons for the necessity of critical thinking. According to the critical pedagogy movement, the critical thinking movement 'enshrine[s] many conventional assumptions as presented by the popular media, traditional textbooks, etc., in a manner that, intentionally or not, teaches political conformity' (Burbules \& Berk, 1999, p. 56). By contrast, the critical thinking movement sees the critical pedagogy movement as dogmatically "uncritical" about their own major assumption, i.e., that the sociopolitical system is the reason for the oppression of the working class, and evidence of many of the social ills in society today.

The following table summarises and clarifies some of the differences between the two movements in relation to critical thinking (CT) (Table 2.3).

\section{The Axis Diagram Revisited Again}

Now we have looked at the critical pedagogy movement (CPM) and distinguished it from the tradition of the critical thinking movement we can position it too on our axis diagram (see below).

The critical pedagogy perspective clearly comes under our category of "Critical Doing" as does the criticality movement. The reason for this is that both emphasize action. However, unlike the criticality movement, which has a non-specific and undirected use of the term "action", the critical pedagogy movement is strident in 
Table 2.3 A comparison between the critical thinking movement and the critical pedagogy movement

\begin{tabular}{|c|c|c|}
\hline & $\begin{array}{l}\text { Critical thinking movement } \\
\text { (CTM) }\end{array}$ & $\begin{array}{l}\text { Critical pedagogy movement } \\
\text { (CPM) }\end{array}$ \\
\hline Aim of CT & $\begin{array}{l}\text { To use reasonable and rational } \\
\text { reflection to interpret the } \\
\text { world, resulting in the } \\
\text { liberation of the intellect }\end{array}$ & $\begin{array}{l}\text { To emancipate people from } \\
\text { oppressive conditions of the } \\
\text { capitalist system, resulting in } \\
\text { the liberation of political } \\
\text { consciousness, leading to } \\
\text { political praxis }\end{array}$ \\
\hline Scope of CT & $\begin{array}{l}\text { To cultivate critical thinking } \\
\text { skills and dispositions, e.g., to } \\
\text { bring about 'reasonable, } \\
\text { reflective thinking focussed } \\
\text { on deciding what to believe or } \\
\text { do' }\end{array}$ & $\begin{array}{l}\text { To bring about social action } \\
\text { to overcome-or at least } \\
\text { question and } \\
\text { critique-oppressive social } \\
\text { conditions ("relations of } \\
\text { domination") }\end{array}$ \\
\hline Involvement & $\begin{array}{l}\text { To use others (teachers, fellow } \\
\text { students, resources) as a } \\
\text { means to cultivating cognitive } \\
\text { skills and critical dispositions }\end{array}$ & $\begin{array}{l}\text { To use dialogue as a means of } \\
\text { developing confidence, } \\
\text { literacy, and thereby } \\
\text { eliminating powerlessness }\end{array}$ \\
\hline Purpose of teaching CT & $\begin{array}{l}\text { To teach critical thinking } \\
\text { skills and dispositions with a } \\
\text { view to creating better } \\
\text { thinkers }\end{array}$ & $\begin{array}{l}\text { To bring about social justice: } \\
\text { to make students aware of } \\
\text { indoctrination, and the social } \\
\text { conditions that led to this, } \\
\text { with a view to allowing them } \\
\text { to escape them }\end{array}$ \\
\hline Agenda of CT & $\begin{array}{l}\text { None: cultural, moral, ethical, } \\
\text { political issues are precluded } \\
\text { as necessary topics for } \\
\text { discussion (Critical thinking } \\
\text { can be done in principle using } \\
\text { abstract formal mathematical } \\
\text { entities and variables, e.g., 'p' } \\
\text { and 'q'.) }\end{array}$ & $\begin{array}{l}\text { Political issues are essential } \\
\text { to critical thinking and are the } \\
\text { reasons why it is vital to do } \\
\text { and promote critical thinking }\end{array}$ \\
\hline Attitude & $\begin{array}{l}\text { "Impartiality" on issues is a } \\
\text { key virtue and is itself a } \\
\text { critical thinking disposition }\end{array}$ & $\begin{array}{l}\text { "Impartiality" on issues is } \\
\text { evidence of domination and } \\
\text { oppression }\end{array}$ \\
\hline Wider context & $\begin{array}{l}\text { Non-relational. Social and } \\
\text { political context is } \\
\text { independent of critical } \\
\text { thinking (though of course } \\
\text { proponents of the CTM are } \\
\text { concerned about social } \\
\text { conditions) }\end{array}$ & $\begin{array}{l}\text { Relational. Social and } \\
\text { political context is intrinsic to } \\
\text { critical thinking }\end{array}$ \\
\hline Criticism of the other & $\begin{array}{l}\text { CPM is blind to critical } \\
\text { thinking about own premises } \\
\text { and assumptions }\end{array}$ & $\begin{array}{l}\text { CTM is insufficiently aware } \\
\text { of its own political } \\
\text { conformity }\end{array}$ \\
\hline
\end{tabular}

Adapted from Burbules and Berk (1999) 
its calls for a specific form of action (and specifically, action in relation to social conditions). I shall call this "Critical Participation". "Doing", in an abstract sense, might be merely undirected, or pointless. "Participation" carries with it a sense of purposeful doing. It carries with it more of a sense of engagement than simply critical doing. It requires engagement with the thing one is acting for, in relation to, or on behalf of. As we have seen, in the case of the critical pedagogues, this "doing" is related to the questioning and reconfiguration of oppressive social conditions. This is central to the aim of theorists such as Freire, Giroux, McLaren and others. But it is also central to related socio-cultural agendas. "Critical participation" is also the natural home for the critical citizenship theorists, and those sympathetic to critical feminist approaches to critical thinking, with their emphasis on criticality as a socially constructed phenomenon, which is inextricably connected to the process of becoming a member of a certain community. Indeed, the metaphor of "participation" is often used in this connection (Salomon \& Perkins, 1998; Sfard, 1998; Ten Dam \& Volman, 2004).

Note that "Critical Participation" is oriented on our diagram spatially closer to the category of "Critical Doing" compared to the category of "Critical Rationality" (it has a stronger "outer" than an "inner" focus). It is positioned closer to the " $\mathrm{X}$ " axis. However, again, there is a difference in the degree of commitment here. The "participation" facet of criticality, in turn, has two dimensions: (1) awareness of oppression (known in the literature "critical consciousness" or-as it is known in the critical pedagogy literature-conscientization (Freire, 1972, 1973); and (2) a more practical dimension, the resistance to oppression (demonstrably, to "resist" something one needs to be aware of what one is resisting). This is sometimes known in the critical pedagogy literature as praxis. Both these vectors are represented in the diagram below (Fig. 2.7).

To the critical pedagogues, the action of resistance to oppressive conditions, by means of action against (amongst other things) educational indoctrination is essential. However, this commitment is foreign to the aim of proponents of the critical thinking movement (even if they happen to agree with it in principle). The CTM (the "Y" axis), in fact, appears neutral with respect to social conditions. Reactionary views on educational oppression have little, if anything, to do with the literature on critical thinking per se. Discussions of the cognitive and propensity elements of critical thinking, it seems, can and is often discussed independently of the socio-cultural axis of criticality.

However, this separation of concerns belies deep similarities. As Burbules and Berk note: "each invokes the term "critical" as a valued educational goal: urging teachers to help students become more skeptical toward commonly accepted truisms. Each says, in its own way, "Don't let yourself be deceived". And each has sought to reach and influence particular groups of educators ... They share a passion and sense of urgency about the need for more critically oriented classrooms. Yet with very few exceptions these literatures do not discuss one another' (Burbules \& Berk, 1999, p. 45).

The fact that the respective literatures do not "discuss each other" is no reason not to include them both in a comprehensive overview of the relative concerns of those interested in critical thinking. I have tried to do this in this paper. Seeing these 


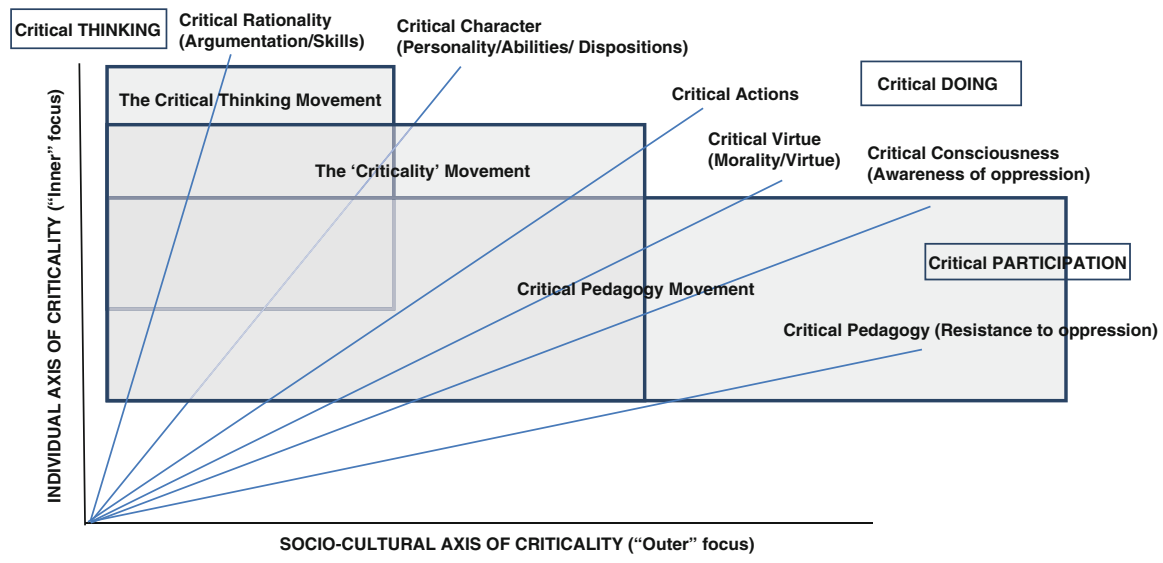

Fig. 2.7 The critical pedagogy movement

respective concerns as different axes or dimensions on one model of critical thinking in higher education, in fact, has intrinsic benefits. It helps in understanding wherein the panoply of possible positions on critical thinking on offer-various theorists are located. It also helps in unraveling axis disputes and axis alignments. For example, note that the critical pedagogy movement is largely disinterested in the concerns of the critical thinking movement, and vice-versa (the shaded sectors in the diagram do not overlap). However, there are synergies between the CPM and the criticality movement as indicated by their focus on action. All these concerns are demonstrably relevant to critical thinking in higher education, broadly conceived even if there may be dramatic differences in matters of detail. The model helps us see these differences. I shall consider another important axis dispute at the end of the paper.

\section{Critical Thinking as Thinking Differently (The "Creativity" View)}

Where to from here? Burbules and Berk, interestingly, see the widening and deepening of critical thinking in terms of "criticality", and thence "critical pedagogy", to hold promise for yet another important sense of "critical thinking". In a section of their paper headed 'Towards an alternate criticality', they attempt to articulate such an account by focusing on the phenomenon of critical thinking as practice. They call this account "Critical thinking as thinking differently". I shall call it critical thinking as creativity or openness $(\mathrm{CAC} / \mathrm{O})$. This account is necessarily rather speculative, but it seems to hold promise of a unique and coherent account of its own. As I am aiming to provide a comprehensive model of critical thinking in higher education, I should include it. 
Burbules and Berk see various movements in the critical thinking literature in terms of any other ideology, e.g., Marxism, fascism, and so on. They claim that all ideologies have an unavoidable appeal and presence; a presence which has a hold over people who are sympathetic to their world-view. All ideologies influence us to the extent that they make us prepared to ignore features of phenomena that lie outside the purview of a given ideology. This, they rightly note, is the main characteristic of ideologies.

Burbules and Berk claim that both the critical thinking movement and the critical pedagogy movement are each themselves examples of an "ideology". Neither is willing to acknowledge the virtues and place of the other as legitimate contenders in any discussion about the nature of critical thinking. Both are concerned with their own preservation. Both are concerned with their own 'reification and stasis' and lack reflective criticism about their limitations. They 'lack ... opportunities to think differently ... and are less able_-and less motivated-to pull up their own roots for examination' (1999, p. 61).

They suggest that this recognition-i.e., that theories about critical thinking are themselves ideologies - is a basis for a new way of thinking about critical thinking. The potential for doing so opens the prospect of seeing critical thinking as 'a way of being as well as a way of thinking' (1999, p. 62 italics added). By this they mean that critical thinking is as much a way of thinking about arguments, dispositions, actions and social relations, as a way of being creative and "open to challenges" of thinking anew (1999, p. 60). True critical thinking, for them, is about not being "closed off". It, instead, begs a requirement for "openness". This, for Burbules and Berk, does not amount to a relativist thesis (the view that all perspectives are equally valid) it amounts to appreciating that un-reconciled (and irreconcilable) tensions exist between different perspectives on critical thinking. Critical thinking as creativity, in their view, also means finding these tensions agreeable, and not being perpetually unsatisfied by them. It is in 'remaining open to challenges without seeking to dissipate them that criticality reveals its value as a way of life' (1999, p. 62). It requires a willingness to 'move against the grain of convention' (1999, p. 62). Hence, they use the phrase "critical thinking as thinking differently", thinking creatively, or-as it might also be termed — critical thinking as openness (CAC/O).

This kind of thesis might be rejected out of hand as being unclear. However, I shall embrace their exhortation to think differently on the question of critical thinking as it applies to higher education. I believe coherent sense can be made of their suggestion by adopting insights from the cognitive sciences. Perhaps a case can be made that true critical thinking only occurs if the whole fibre of one's personality/physical body/consciousness/emotions as well as actions are involved. That is, critical thinking is not merely rational/intellectual/definitional/judgmental, but nor is it simply disassociated bodily actions in response to reasoned decisionmaking. "True" critical thinking might be all of these things and more. In particular, it might include thinking that involves a number of facets of cognition not easily understood in terms of the axes of skills, judgments, dispositions and actions as previously outlined. These features of thinking include expertise in pattern and similarity recognition, common sense understanding, skilled "know-how" (in the 
Rylean sense), an ability of seeing situational salience (where some real-world events are instantaneously, and unconsciously, perceived as more important than others), and what is known as deliberative rationality (i.e., the ability to use expertise to interpret new events in terms of past experience and to make instantaneous, unconscious, confident decisions based on them). All of the above are familiar in the cognitive science literature as the "six aspects of intuitive judgment" (Dreyfus \& Dreyfus, 1985). This kind of thinking, in short, is intuitive thinking, a very different kind of thinking to that discussed earlier. This, along with creative thinking, surely has a strong relationship to critical thinking (Paul \& Elder, 2008). Unfortunately, however, there has been very little work done on this.

Intuitive thinking occurs only when a great deal of reasoning, and practice with reasoning, assessment of evidence, and so on has already occurred. Intuitive thinking is based on past decisions grounded in sound, well-established principles of critical thinking. However intuitive thinking is marked by the thinker having gone beyond conscious intellectual consideration of their judgments and decisionmaking. This kind of thinking involves having constructed a large number of cognitive patterns from which to make immediate, unconscious "intuitive" calls to action. This phenomenon is common amongst "expert" thinkers in a range of professions (Ericsson, 2008; Ericsson \& Lehmann, 1996). For experts, intellectual consideration has become incorporated into bodily consideration and action as an intuitive response. A sportsman effortlessly and unconsciously "knows" how to play the ball, or take a tackle; the musician just "knows" how to phrase the passage, and so on.

In this sense, "true" critical thinking must necessarily be "open" in relation to all influences. It involves thinking differently_being trans-critical-i.e., thinking with the core of one's body and being-not merely thinking intellectually. This does not mean trans-rational (beyond reason), rather, it means rational thinking albeit not thinking that involves conscious analytical methods of decision-making (Franz, 2003). As noted, this phenomenon has a parallel in the area of sports, music and other areas, and is sometimes known as "the Zone" or the phenomenon of "flow" (Cooper, 2009; Csikszentmihalyi, 1990). Its characteristic features are a heightened sense of mastery and emotional buoyancy.

At first blush this might seem completely counter to critical thinking. However, in outlining the perspectives of the various traditional accounts of critical thinking in this paper, it might be noted that all of them to date (with possible exception of the account by Burbules and Berk) neglect the importance of the role of the intuition and creativity in critical thinking. This seems to us to be an oversight. The importance of intuitive thinking, intuitive reasoning-thinking trans-criticallyis becoming increasingly important to the cognitive sciences and brain science research, with published studies arising on the role of intuitive reasoning in areas as diverse as expert sports performance, chess-playing, judgment-making in nursing and other professions, management decision-making, and solving physics problems (Benner \& Tanner, 1987; Dane \& Pratt, 2007; Effken, 2000; Ericsson, 2008; Larkin, McDermott, Simon, \& Simon, 1980; Lieberman, 2000). 
Intuition is sometimes defined as 'understanding without a rationale' (Benner \& Tanner, 1987, p. 23). But this would be to underplay its significant role in brain processing. The evidence so far adduced from the cognitive sciences seems to indicate that creative "intuition" is no mysterious process as it is often assumed to be, but a process involving the cognitive agent being able to unconsciously search across knowledge domains and indexed patterns of reliable information in a fraction of a second to access relevant parts of an established information store (Franz, 2003). It involves the expert's body being part of engagement in the world; a form of "knowing how" in which tools and objects become-in a Heideggerian sense-extensions of the their own body (as when a nurse, for example, feels an intravenous catheter to be 'an extension of her fingers, not an unwieldy foreign object' (Benner \& Tanner, p. 26)). Evidence suggests that this form of thinkingintuitive thinking - is more efficient, and accurate, than conventional thinking involving reasoned weighing up of alternatives (Lieberman, 2000, p. 109). A more accurate definition suggests that intuitive thinking be considered 'the subjective experience associated with the use of knowledge gained through implicit learning' (Lieberman, p. 109), or as a 'phenomenological and behavioural correlate of implicit learning' (Lieberman, p. 126). Sometimes intuitive thinking is seen in terms of "thin slicing" (Gladwell, 2005). This is the remarkable capacity of humans who, instantaneously, and without conscious effort, can sift through a situation, zero in on what is salient, throw everything out that is not relevant, and act accordingly. It would be remiss of researchers not to consider the importance of intuitive thinking for any complete account of critical thinking.

Moreover, there is a point of consistency to consider. We have seen, in the taxonomy of the various positions I have provided, how the framework of criticality has been be extended from (initially) a very narrow account of skills in argumentation, to the importance of including broader cognitive skills, actions and emotions, and then the inclusion of dispositions, actions, social relations, and now creativity. Each development has consisted of an expansion of the conception of critical thinking for higher education. It is not a difficult step to imagine the need to include creative intuitions as well. However, I am not suggesting this as an additional account of criticality to that already proposed. I am suggesting that intuitive critical thinking is already implicit in the account of creative critical thinking $(\mathrm{CAC} / \mathrm{O})$.

The CAC/O view just outlined can be compared with Barnett's example of the Chinese Tank Man provided earlier as an exemplar of critical being, and noted also as an example of critical action (see p. ?). As noted then, the man's actions clearly were not entirely intellectual in nature (indeed, had he had thought critically about it he surely would not have done it). His sizing up of the situation and acting was an intuitive act-an organic critical response to the context. His action was the opposite of weighing an argument, assessing it dispassionately, etc. It was in another vector space to critical thinking as argumentation (the " $Y$ " axis in our axis diagram). Just as a mother would not even think about a brave, unself-serving action to protect her off-spring in response to a perceived danger-or an accomplished sportsperson would not even need to think how to make the play-so too, a "true" critical thinker responds intuitively with organic, bodily responses. Conscious intellect is 
suspended: they are not convinced of the rightness of their actions, intellectuallyspeaking, as much as responding instinctively and intuitively to what they need to do. The cognitive science literature suggests this is a real phenomenon.

To what extent this idea is a coherent notion, and to what extent it constitutes a valuable contribution to critical thinking theory remains to be seen. However, it has clear similarities to Barnett's valuable notion of critical being. I therefore propose this as having a location in the final contribution to our axis diagram below (as the "X" axis in our diagram). It shows how critical openness is premised on the importance of intuition as part of critical thinking, i.e., criticality as critical being. The latter is represented in the model as a diametrically opposed vector space than the CTM.

The location of critical creativity on the diagram shows how the perspective of critical thinking and openness keeps "open" all previous views of critical thinking (hence the lines representing all forms of critical thinking intersect through the shaded block). By contrast, the CTM only has argumentation/skills and abilities/disposition lines intersecting in its shaded block. Thus, while the CTM is very narrow in its focus the alternative, $(\mathrm{CAC} / \mathrm{O})$, is open to all influences. This makes the CTM more easily understood as an account of critical thinking and more productive in its output. It also means that the alternative-critical thinking as creativity or openness $(\mathrm{CAC} / \mathrm{O})$ - seems, on the surface, to be woolly and less clear. But this does not make the latter wrong. To suggest otherwise is another potential axis dispute from the narrow perspective of protagonists aligned with, and sympathetic to, a different dimension of critical thinking, a different critical thinking "ideology".

It is for future work to determine whether this account of the various positions on critical thinking can be maintained. I submit it as part of a model of critical thinking that helps to make sense of a variety of considerations in the critical thinking in higher education literature. The final iteration of the axis diagram is given below (Fig. 2.8).

\section{A Practical Example}

How can these various positions on critical thinking be explained using a simple example? By using and extending the example of a lawyer, used earlier, we can see a number of discrete stages involved in the process of being a critical thinker. For completeness sake, I include the first six stages representing Bloom's famous taxonomy (the final three stages approximating cognitive critical thinking skills). In addition, we can see the locus of interest of all the major views about critical thinking. Given what has been outlined earlier, it is important to note that the examples below are not indicative of discrete "stages" or "levels", but rather overlapping dimensions. What I have called "axis disputes" can occur between dimensions (Table 2.4). 


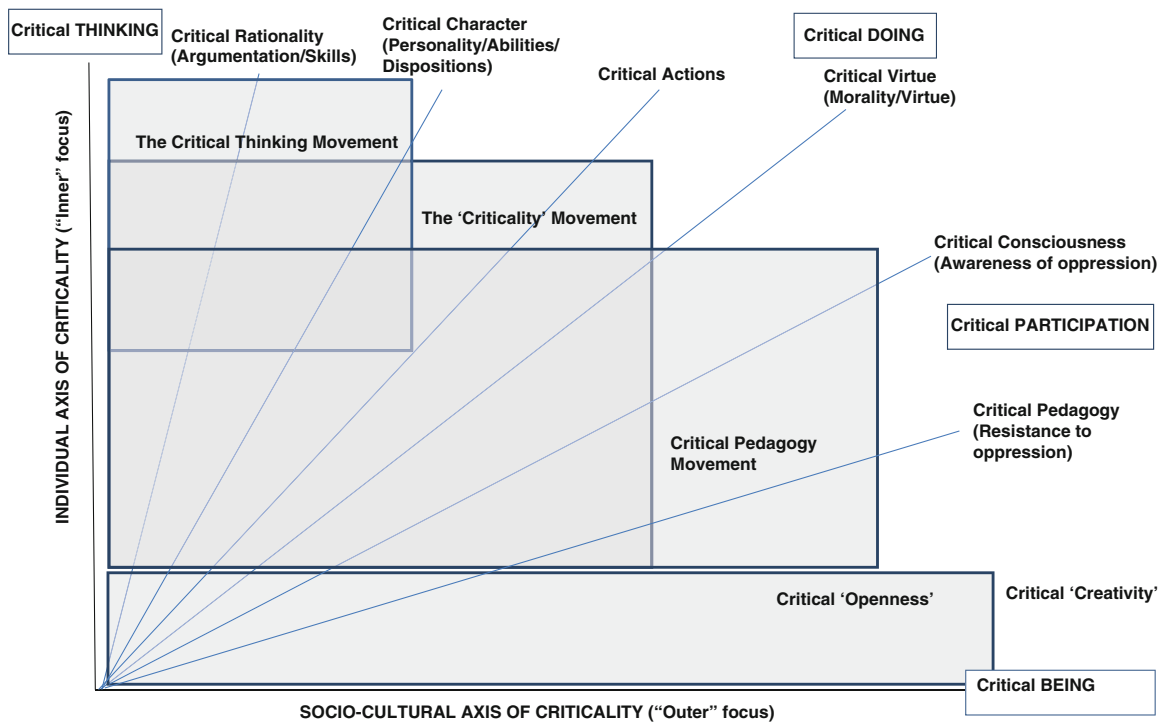

Fig. 2.8 The individual and socio-cultural elements of critical thinking

\section{A Model of Critical Thinking in Higher Education}

The enterprise of critical thinking in higher education, I submit, can be seen in terms of a series of concentric circles (see Fig. 2.9). I propose this as a model for critical thinking in Higher Education.

\section{Explaining the Model}

What is the relationship between the axis diagram and the circles diagram? The circles diagram constitutes my model of critical thinking in higher education. The axis diagram was necessary getting us to that point. It was important as a preparatory stage in outlining, in a visual way, the various accounts of critical thinking; it showed the geography or terrain of the various positions in relation to one another. Ideally, the model proposed should be $3 \mathrm{D}$, including the various axes. However, it is also important that the model of critical thinking represents the disparate perspective as of a piece; as comprising Wittgensteinian "family resemblances" as it wereaspects of a single concept in use. This is because critical thinking, while complex, is one phenomenon. All the positions on critical thinking, while occupying different vector spaces on the model, contribute something different to our understanding of critical thinking as a single, undifferentiated (although multi-faceted) concept. The axis diagram then can be considered a useful fiction. In a similar way, the Bohr-Rutherford model of an atom is a useful fiction. However, both point to way to understanding the phenomenon under investigation. 
The circles of critical thinking radiate out from a focus on the individual and his or her cognitive skills and dispositions (the individual dimension or axis); to a focus on the individual and his or her actions; to a focus on the individual in relation to others in a wider social and educational context; and finally, to a focus of the social context itself in which the individual thinker operates in a critically engaged citizen (the socio-cultural dimension or axis). It is the latter which critical pedagogues see as constituting oppressive social conditions in need of critique.

The "inner" circles constitute the "critical thinking movement" as it is broadly understood to include cognitive factors and propensity elements (these are shaded to indicate their centrality and importance to critical thinking theory as it is understood historically). All the circles are drawn with dotted lines indicating a degree of permeability between each level. Thus, a major figure in the CTM such as

Table 2.4 The relationship between different accounts of critical thinking in higher education

\begin{tabular}{|c|c|c|}
\hline \multirow{5}{*}{ Bloom's taxonomy } & Level of Criticality & Sample Case \\
\hline & Knowledge & A lawyer can define a legal principle such as "innocent until proven guilty". \\
\hline & Comprehension & $\begin{array}{l}\text { A lawyer can explain the purpose of a legal principle such as "innocent until } \\
\text { proven guilty". }\end{array}$ \\
\hline & Application & $\begin{array}{l}\text { A lawyer can give a concrete example of a legal principle such as "innocent } \\
\text { until proven guilty". }\end{array}$ \\
\hline & Analysis & $\begin{array}{l}\text { A lawyer can compare and contrast the application of a given principle such as } \\
\text { "innocent until proven guilty" in relation to a number of legal cases. }\end{array}$ \\
\hline \multirow{3}{*}{$\begin{array}{l}\text { Critical } \\
\text { Thinking } \\
\text { Movement }\end{array}$} & Synthesis & $\begin{array}{l}\text { A lawyer can classify and assess the likely or probable outcome of a legal } \\
\text { case as a result of the application of a legal principle such as "innocent until } \\
\text { proven guilty". }\end{array}$ \\
\hline & Evaluation & $\begin{array}{l}\text { A lawyer can make a judgment about, and draw conclusions about, the } \\
\text { outcome of a legal decision in relation to the application of a legal principle } \\
\text { such as "innocent until proven guilty" and can deliberate on the value and } \\
\text { worth of the principle itself. }\end{array}$ \\
\hline & Critical action & $\begin{array}{l}\text { A lawyer can act on a legal principle such as "innocent until proven guilty" } \\
\text { (i.e., the lawyer can do more than analyse, synthesise and evaluate, they can } \\
\text { engage in concrete actions in relation to the principle). This demonstrates } \\
\text { more than critical thinking, it demonstrates critical character (acting on } \\
\text { principle). However, these actions need not necessarily be in relation to a } \\
\text { fair and just cause. }\end{array}$ \\
\hline $\begin{array}{l}\text { Criticality } \\
\text { Movement }\end{array}$ & Critical virtue & $\begin{array}{l}\text { A lawyer can act virtuously on a legal principle such as "innocent until proven } \\
\text { guilty" by defending a client whom they believe is truly worthy of defence, and } \\
\text { refusing to act in relation to unworthy cases. This is to be distinguished from } \\
\text { merely engaging in concrete actions in order to win cases (i.e., with no moral } \\
\text { compunction at all). }\end{array}$ \\
\hline
\end{tabular}


Table 2.4 (continued)

\begin{tabular}{|c|c|c|}
\hline \multirow[t]{2}{*}{$\begin{array}{l}\text { Critical } \\
\text { Pedagogy } \\
\text { Movement }\end{array}$} & $\begin{array}{l}\text { Critical } \\
\text { consciousness }\end{array}$ & $\begin{array}{l}\text { A lawyer can be cognisant of wider inequities beyond legal principles such as } \\
\text { "innocent until proven guilty". These wider inequities are a result of social } \\
\text { conditions occurring beyond the case in question that might have an impact } \\
\text { on the clients' case. The lawyer is thereby concerned about the root causes of the } \\
\text { situation that led to the case as much as the case itself. }\end{array}$ \\
\hline & Critical pedagogy & $\begin{array}{l}\text { A lawyer is prepared to take a stand on the wider social injustices/root causes } \\
\text { that arise in relation to legal principles such as "innocent until proven guilty" as } \\
\text { they might apply in relation to his/her client. The lawyer does not thereby merely } \\
\text { act virtuously in relation to his/her case. Instead, he/she is prepared to act } \\
\text { virtuously in relation to wider social concerns. In particular, this means } \\
\text { changing the educational system that lead to the inequities. }\end{array}$ \\
\hline $\begin{array}{l}\text { Critical } \\
\text { 'Openness' }\end{array}$ & Critical Being & $\begin{array}{l}\text { A lawyer no longer sees his/her case as merely acting in relation to an application } \\
\text { of legal principle such as "innocent until proven guilty" in relation to a client. } \\
\mathrm{He} / \text { she is past the stages of critical analysis, synthesis and evaluation and action. } \\
\mathrm{He} / \text { she is convinced of the rightness of his/her judgments and the urgency of } \\
\text { doing something about it. He/she is wholly absorbed in the fullest sense in the } \\
\text { wrongfulness of the situation. He/she is instinctively responsive to the situation } \\
\text { and is prepared to do anything to remedy it. The clients' case has become a } \\
\text { secondary concern. The issue has become central to the lawyer's life. }\end{array}$ \\
\hline
\end{tabular}

R. H. Ennis, who initially focused on defining critical thinking as a cognitive skill, 'as the correcting assessing of statements' (the innermost circle), has modified his stance to incorporate critical thinking judgments and dispositions, i.e., 'reasonable, reflective thinking focused on what to believe or do'. Thus, his account has shifted from the inner-most circle to the second. This indicates some natural evolution in his perspective. (He also countenances dispositions, and therefore can be located in the third circle as well.) Similarly, other theorists have modified their initial views, usually adopting "wider" perspectives from that they held originally.

These different concerns of the various critical thinking movements are, respectively:

1. Critical thinking as (a) cognitive skills and (b) judgments, i.e., critical thinking as argumentation and reflection (The cognitive dimension);

2. Critical thinking as each of these in addition to affective factors, i.e., dispositions, emotions, attitudes and state of readiness (the propensity dimension);

3. Critical thinking as all of these in addition to actions (the "criticality" dimension);

4. Critical thinking as all of these in addition to social relations (the "critical pedagogy" dimension).

Finally, Burbules and Berk (1999) offer the prospect of a fifth dimension-a sixth circle - of critical thinking as creativity $(\mathrm{CAC} / \mathrm{O})$. This account of critical thinking in higher education, however, is highly speculative and undeveloped at this point. I suggested a naturalist reading of this suggestion consistent with their notion of 


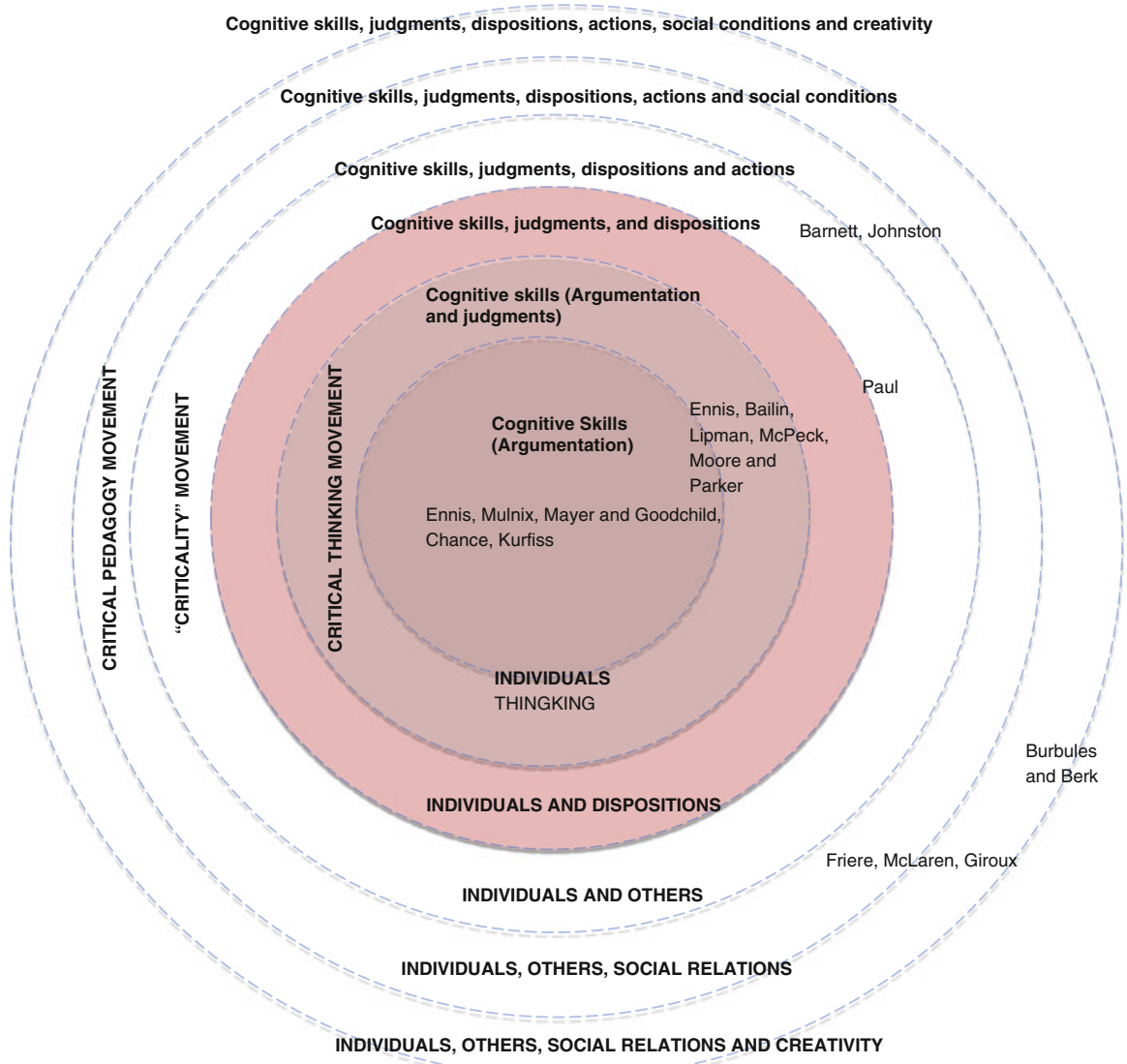

Fig. 2.9 A model of critical thinking in higher education

critical thinking as creativity. This intriguing idea needs sustained discussion that I cannot attempt here.

The three innermost circles (argumentation, judgments, and dispositions) constitute the critical thinking movement as it is generally understood, i.e., as a movement consisting mainly of educational philosophers seeking to define and create taxonomies of the concept of "critical thinking". These innermost circles have a focus on critical thinking at the individual level. The fifth and sixth circles focus on critical thinking at the social level. The fourth circle is an intermediate stage constituting what I have referred to as the "criticality movement", although this cause is fairly new, and is not identified as such in the literature. This is a group of scholars consisting mainly of higher education specialists interested in the wider ramifications of critical thinking for higher education, tertiary institutions, and society at large. The fifth circle constitutes a movement of educational radicals working at the intersection of philosophy, higher education, pedagogy, and politics. 
This is what is customarily known as the critical pedagogy movement. The sixth outermost circle is constitutive of a possible extension of the scholarship of critical thinking into a stage of intuitive thinking and critical being, but remains underdeveloped.

Historically, the concerns of the critical pedagogues (fifth circle) have been seen by philosophers in the critical thinking movement (three innermost circles) as having concerns that are tangential and oblique to their main aims. As Burbules and Berk put it, they would regard the concern for social inequity, inequality and disenfranchisement, as important, but 'subsidiary to the more inclusive problem of people basing their life choices on unsubstantiated truth claims-a problem that is non-partisan in its nature or effects' (Burbules \& Berk, 1999, p. 46). In other words, for proponents of the critical thinking movement, the definitional and justification issues associated with critical thinking come first; politics comes second. However, importantly, as our model suggests, this is a matter of preference and emphasis. It is an axis dispute. There is no a priori reason why scholars cannot investigate critical thinking along all dimensions outlined simultaneously; indeed, a fully satisfactory account of critical thinking in higher education-as opposed to a localized, philosophical treatment of critical thinking-will need to run orthogonally to the circles and not be confined in the "orbit" of any particular dimension.

\section{Advantages of the Model}

There are at least three main advantages offered by the model.

Firstly, the model also helps us see, at a glance, how those working in the area relate to each other. Key proponents of each position are shown in the diagram with their approximate locus indicated. Ennis and colleagues are centrally-placed in the cognitive "skills"-based camp, though, as noted, many of these thinkers also sympathetic to the dispositional approach (hence the shaded section which extends out to the third circle). Paul is an outlier in this camp, as he has demonstrated a willingness to consider social ramifications and concerns (Burbules \& Berk, 1999, pp. 50, 53). Barnett and Johnston are representatives of the "criticality" movement circle demonstrating their commitment to critical action as a vital part of critical thinking in higher education, and their concern with the role of critical thinking in society, i.e., educating for participation in the world as a critical, engaged citizen (although not a radicalized citizen railing against oppression). The social pedagogues, Friere, Grioux, McLaren and others, are even further out, tangential to, and largely unconcerned with, the "skills" debate. They are firmly located in the circle that commits to social relations being an essential part of radical critical thinking. The outermost circle is the home of those which see critical thinking as an open, creative pursuit. This view captures the notion of critical thinking as intuitive, trans-critical responsiveness.

Secondly, the model promises a rapprochement of sorts between the critical thinking movement (the three innermost circles) and the critical pedagogy move- 
ment (fifth circle). This is by means of the fourth, intermediary and connecting circle. The emphasis placed by Barnett and others on "criticality" —as opposed to critical thinking or critical pedagogy_provides a point on which both parties can agree, and on which they can leverage their respective interests. Like those in the "criticality" movement, proponents of the critical thinking movement acknowledge - albeit inadequately account for-the importance of action. Likewise, the proponents of the critical pedagogy movement seem to acknowledgeindeed, mandate - the importance of a wider, social context of critical thinking. Proponents of the criticality movement sit astride both views: neither wanting to fully adopt a radical politico-social agenda, nor wanting to reduce critical thinking to argumentation, judgments and dispositions. Criticality theorists might be considered socio-politically neutral while being simultaneously dissatisfied by restrictions to cognitive definitions of critical thinking.

Thirdly, the model helps to identify axis or boundary disputes. A long-standing example of such a dispute is the debate between "generalist" and the "specifist" approaches to critical thinking (Davies, 2006, 2013; Moore, 2004, 2011). Is critical thinking best understood as a pan-disciplinary phenomenon, or is it best seen as specific to the disciplines? No debate has polarized scholars of critical thinking more than this. How can the model provided illuminate this issue?

The model suggests a ready, if not altogether satisfactory, resolution. If critical thinking is seen principally in terms of developing individual skills in argumentation, judgments, and dispositions, then it is very much a general skill, congruent with many disciplines (as all disciplines use arguments). If, on the other hand, if critical thinking is seen as a matter of being socialized-i.e., acting and participating in a discipline (in the same way, perhaps, as participating as a citizen in a given society) - then this requires dedicated pedagogies for this purpose, and disciplinespecific induction. Depending on one's initial assumptions then, critical thinking is as much a socio-cultural issue as a matter of developing individual skills. From this perspective both views are largely correct and the "debate" is a non-starter. However, sometimes one view is more important for practical reasons. Educating for criticality sometimes demands a myopic view (students need to be able to argue effectively), and sometimes it demands a hyperopic view (students need to develop critical membership or citizenship of certain academic communities). Sometimes one or other requirement is preeminent, and effectively dominates the debate. This decision can turn, not always on matters of educational principle, but on funding decisions and resource allocation in cash-strapped tertiary institutions. In the end what kind of student does an institution want to educate?

Axis disputes do not mean issues are any less disputes; the model makes sense of how debates arise, it does not adjudicate between them. Theoretical models are, likewise, no panacea. They can, however, offer the potential for moving forward in the important area of critical thinking in Higher Education. 


\section{Conclusion}

This paper has overviewed some of the major positions on the nature of critical thinking as they apply to the discipline of Higher Education. This included contributors to the so-called critical thinking movement, the proponents of criticality theory, the critical pedagogues, and those working in critical citizenship and allied fields. While the various perspectives offered on critical thinking in higher education differ in a number of respects, the model provided helps to locate these positions, and the scholars that hold them, in terms of their relative proximity. This might help to avoid the problem of scholars within different fields of critical thinking scholarship "talking past one another". However, the model provided is only a rough sketch. Further work needs to be done in outlining how the model can illuminate important issues in the field. Locating various positions on a model of critical thinking in higher education might be intrinsically interesting, but the important work to be done is providing insight on how critical thinking can be best taught and incorporated in the curriculum. This is where the real value of the model will be tested.

\section{References}

Airasian, P. W., Cruikshank, K. A., Mayer, R., Pintrich, P. R., Raths, J., \& Wittrock, M. C. (2001). A taxonomy for learning, teaching, and assessing: A revision of Bloom's taxonomy of educational objectives. New York: Longman.

Arum, R., \& Roska, J. (2011). Academically adrift: Limited learning on college campuses. Chicago/London: The University of Chicago Press.

Bailin, S., Case, R., Coombs, J. R., \& Daniels, L. B. (1999). Conceptualizing critical thinking. Journal of Curriculum Studies, 31(3), 285-302.

Barnett, R. (1997). Higher education: A critical business. Buckingham, UK: Open University Press.

Barnett, R. (2004). Learning for an unknown future. Higher Education Research and Development, 23(3), 247-260.

Benner, P., \& Tanner, C. (1987, January). How expert nurses use intuition. The American Journal of Nursing, 87(1), 23-34.

Bloom, B. S. (1956). Taxonomy of educational objectives: The classification of educational goals. Handbook I: Cognitive domain. New York: McKay.

Boostrum, R. (1994). Developing creative and critical thinking: An integrated approach. Lincolnwood, IL: National Textbook Company.

Brookfield, S. (1987). Developing critical thinkers: Challenging adults to explore alternative ways of thinking and acting (1st ed.). San Francisco: Jossey-Bass Inc.

Burbules, N. C., \& Berk, R. (1999). Critical thinking and critical pedagogy: Relations, differences, and limits. In T. Popkewitz (Ed.), Critical theories in education: Changing terrains of knowledge and politics (pp. xv, 254 p.). New York: Routledge.

Chance, P. (1986). Thinking in the classroom: A survey of programs. New York: Teachers' College, Columbia University.

Cooper, A. (2009). In the zone: The zen of sports. Patheos, October 16, from http://www.patheos. com/Resources/Additional-Resources/In-the-Zone.html 
Cowden, S., \& Singh, G. (2013). Acts of knowing: Critical pedagogy in, against and beyond the university. London: Bloomsbury Academic.

Csikszentmihalyi, M. (1990). Flow: The psychology of optimal experience. New York: Harper and Row.

Cuban, L. (1984). Policy and research dilemmas in the teaching of reasoning. Review of Educational Research, 54(4), 655-681.

Dane, E., \& Pratt, M. G. (2007). Exploring intuition and its role in managerial decision making. Academy of Management Review, 32(1), 33-54.

Davies, W. M. (2006). An 'infusion' approach to critical thinking: Moore on the critical thinking debate. Higher Education Research and Development, 25(2), 179-193.

Davies, M. (2013). Critical thinking and disciplines reconsidered. Higher Education Research and Development, 32(4), 529-544.

Dreyfus, H., \& Dreyfus, S. (1985). Mind over machine: The power of human intuition and expertise in a era of the computer. New York: Free Press.

Effken, J. A. (2000). Informational basis for expert intuition. Nursing Theory and Concept Development or Analysis, 32(2), 246-255.

Ennis, R. (1991). Critical thinking: A streamlined conception. Teaching Philosophy, 14(1), 5-24.

Ennis, R. H. (2011, July 1994, revised and updated). The nature of critical thinking: An outline of critical thinking dispositions and abilities. Paper presented at the sixth international conference on thinking. Cambridge, MA: MIT. http://faculty.education.illinois.edu/rhennis/documents/ TheNatureofCriticalThinking_51711_000.pdf

Ennis, R. H. (1962). A concept of critical thinking. Harvard Educational Review, 32(1), 81-111.

Ennis, R. H. (1985a). Critical thinking and the curriculum. National Forum, 65, 28-31.

Ennis, R. H. (1985b). A logical basis for measuring critical thinking skills. Educational Leadership, 43(2), 44-48.

Ennis, R. H. (1987). A taxonomy of critical thinking abilities and dispositions. In J. S. Baron \& R. H. Sternberg (Eds.), Teaching thinking skills (pp. 9-26). New York: W.H. Freeman.

Ennis, R. H. (1990). The rationality of rationality: Why think critically? In R. Page (Ed.), Philosophy of education 1989 (pp. 402-405). Bloomington, IL: Philosophy of Education Society.

Ennis, R. H. (1994, April 7). Assessing critical thinking dispositions: Theoretical considerations. Paper presented at annual meeting of the American Education Research Association, New Orleans, LA.

Ennis, R. H. (1996). Critical thinking. Upper Saddle River, NJ: Prentice Hall.

Ericsson, K. A. (2008). Deliberate practice and acquisition of expert performance: A general overview. Academic Emergency Medicine, 15, 988-994.

Ericsson, K. A., \& Lehmann, A. C. (1996). Expert and exceptional performance: Evidence of maximal adaptation to task constraints. Annual Review of Psychology, 47, 273-305.

Facione, P. (1998). Critical thinking: What it is and why it counts? Millbrae, CA: California Academic Press. www.insightassessment.com/pdf_files/what\&why2006.pdf

Facione, P. (2000). The disposition toward critical thinking: Its character, measurement, and relation to critical thinking skills. Informal Logic, 20(1), 61-84.

Facione, P., \& Facione, N. (1992). The California Critical Thinking Dispositions Inventory (CCTDI) and the CCTDI manual. Millbrae, CA: Academic.

Facione, P. A. (1990). The Delphi Report: Critical thinking: A statement of expert consensus for purposes of educational assessment and instruction. Millbrae, CA: California Academic Press.

Facione, P. A., Sanchez, C. A., Facione, N. C., \& Gainen, J. (1995). The disposition toward critical thinking. The Journal of General Education, 44(1), 1-25.

Fisher, A., \& Scriven, D. (1997). Critical thinking: Its definition and assessment. Point Reyes, CA: Edgepress.

Franz, R. (2003). Herbert Simon. Artificial intelligence as a framework for understanding intuition. Journal of Economic Psychology, 24, 265-277.

Freire, P. (1972). Pedagogy of the oppressed. Harmondsworth, UK: Penguin.

Freire, P. (1973). Education for critical consciousness. New York: Seabury Press. 
Giroux, H. A. (1988). Teachers as intellectuals. Granby, MA: Bergin and Garvey.

Giroux, H. A. (1994). Toward a pedagogy of critical thinking. In K. S. Walters (Ed.), Re-thinking reason: New perspectives in critical thinking (pp. 200-201). Albany, NY: SUNY Press.

Giroux, H. A. (2005). Border crossings: Cultural workers and the politics of education. New York: Routledge.

Giroux, H. A. (2010, October 17). Lessons from Paulo Freire. The Chronicle of Higher Education. Retrieved from http://chronicle.com/article/Lessons-From-Paulo-Freire/124910/ October 18,2012

Gladwell, M. (2005). Blink: The power of thinking without thinking. New York: Back Bay Books/Little, Brown and Company.

Halonen, J. (1986). Teaching critical thinking in psychology. Milwaukee, WI: Alverno Publications.

Halonen, J. (1995). Demystifying critical thinking. Teaching of Psychology, 22(1), 75-81.

Halpern, D. (1997). Critical thinking across the curriculum: A brief edition of thought and knowledge. Mahwah, NJ: Lawrence Erlbaum and Associates.

Halpern, D. (1998). Teaching critical thinking for transfer across domains: Dispositions, skills, structure training, and metacognitive monitoring. American Psychologist, 53(4), 449-455.

Hennessey, M. G. (1999). Probing the dimensions of metacognition: Implications for conceptual change teaching-learning. Paper presented at the annual meeting of the National Association for Research in Science Teaching, Boston, MA.

Ip, W., Lee, D. T., Lee, I. F., Chau, J. P., Wootton, Y. S., \& Chang, A. M. (2000). Disposition towards critical thinking: a study of Chinese undergraduate nursing students. Journal of Advanced Nursing, 32(1), 84-90.

Johnston, B., Ford, P., Mitchell, R., \& Myles, F. (2011). Developing student criticality in higher education. London: Continuum.

Kaplan, L. D. (1991). Teaching intellectual autonomy: The failure of the critical thinking movement. Educational Theory, 41(4), 361-370.

Kennedy, M., Fisher, M. B., \& Ennis, R. H. (1991). Critical thinking: Literature review and needed research. In L. Idol \& B. F. Jones (Eds.), Educational values and cognitive instruction: Implications for reform (pp. 11-40). Hillsdale, NJ: Lawrence Erlbaum and Associates.

King, F. J., Goodson, L., \& Rohani, F. (n.d.). Higher order thinking skills: Definition, teaching strategies, assessment. Tallahasee, FL: Center for the Advancement of Learning and Assessment Florida State University. http://www.cala.fsu.edu/files/higher_order_thinking_skills.pdf

Knight, P. (2007). Fostering and assessing 'Wicked' competencies. Milton Keynes, UK: Institute of Education, Open University. Retrieved from http://www.open.ac.uk/cetl-workspace/ cetlcontent/documents/460d1d1481d0f.pdf

Kuhn, D. (1999). A developmental model of critical thinking. Educational Researcher, 28(2), $12-$ $25+46$.

Kuhn, D., \& Dean, D. (2004). A bridge between cognitive psychology and educational practice. Theory Into Practice, 43(4), 268-273.

Kurfiss, J. (1988). Critical thinking: Theory, research, practice and possibilities (ASHE-Eric higher education report no. 2). Washington, DC: Associate for the Study of Higher Education.

Lai, E. R. (2011, June). Critical thinking: A literature review. Retrieved from http://www. pearsonassessments.com/hai/images/tmrs/CriticalThinkingReviewFINAL.pdf

Langer, E. J. (1989). Mindfulness. Reading, MA: Addison-Wesley Publishing Co.

Larkin, J. H., McDermott, J., Simon, D. P., \& Simon, H. A. (1980). Expert and novice performance in solving physics problems. Science, 208(4450), 1335-1342.

Lieberman, M. D. (2000). Intuition: A social cognitive neuroscience approach. Psychological Bulletin, 126(1), 109-137.

Lipman, M. (1988). Critical thinking: What can it be? Educational Leadership, 46(1), 38-43.

Martinez, M. E. (2006). What is metacognition? Phi Delta Kappan, 87(9), 696-699.

Mayer, R., \& Goodchild, F. (1990). The critical thinker. New York: Wm. C. Brown.

McLaren, P., \& Hammer, R. (1989). Critical pedagogy and the postmodern challenge. Educational Foundations, 3(3), 29-62. 
McPeck, J. E. (1981). Critical thinking and education. New York: St Martin's Press.

Moore, B., \& Parker, R. (1991). Critical thinking (3rd ed.). Mountain View, CA: Mayfield Publishing Company.

Moore, T. (2004). The critical thinking debate: How general are general thinking skills? Higher Education Research and Development, 23(1), 3-18.

Moore, T. (2011). Critical thinking and disciplinary thinking: A continuing debate. Higher Education Research and Development, 38(4), 506-522.

Morse, B. (2012). Why critical thinking is overlooked by schools and shunned by students. The Guardian. Retrieved from http://www.guardian.co.uk/teacher-network/2012/sep/12/criticalthinking-overlooked-in-secondary-education

Mulnix, J. W. (2012). Thinking critically about critical thinking. Educational Philosophy and Theory. doi:10.1111/j.1469-5812.2010.00673.x.

Nelson, J. (2005). Cultivating judgment: A sourcebook for teaching critical thinking. Stillwater, OK: New Forums Press.

Noddings, N. (1992). The challenge to care in schools. New York: Teachers College Press.

Passmore, J. (1967). On teaching to be critical. Boston: Routledge and Kegan Paul.

Paul, R. (2011). Critical thinking movement: 3 waves. Retrieved from http://www.criticalthinking. org/pages/critical-thinking-movement-3-waves/856. 20 May 2013.

Paul, R., \& Elder, L. (2001). Miniature guide to critical thinking: Concepts \& tools. Dillon Beach, CA: Foundation for Critical Thinking.

Paul, R., \& Elder, L. (2008). The thinkers' guide to nature and functions of critical and creative thinking. Dillon Beach, CA: Foundation for Critical Thinking.

Paul, R. W. (1981). Teaching critical thinking in the 'strong' sense: A focus on self-deception worldviews, and a dialectical mode of analysis. Informal Logic, 4(2), 2-7.

Paul, R. W. (1990). Critical thinking: What, why, and how? In A. J. A. Binker (Ed.), Critical thinking: What every person needs to survive in a rapidly changing world. Rohnert Park, CA: Center for Critical Thinking and Moral Critique, Sonoma State University.

Paul, R. W. (1992a). Critical thinking: What every person needs to survive in a rapidly changing world. Santa Rosa, CA: Foundation for Critical Thinking.

Paul, R. W. (1992b). Critical thinking: What, why and how? New Directions for Community Colleges, 77, 3-24.

Paul, R. W. (1993). Critical thinking: What every person needs to survive in a rapidly changing world. Santa Rosa, CA: Foundation for Critical Thinking.

Perkins, D., Jay, E., \& Tishman, S. (1992). Assessing thinking: A framework for measuring critical thinking and problem solving skills at the college level. Washington, DC: The National Center for Educational Statistics Workshop on the Assessment of Higher Order Thinking and Communication Skills of College Graduates: Preliminary Listing of Skills and Levels of Proficiency.

Ryle, G. (1963). The concept of mind. Harmondsworth, UK: Penguin.

Sadler, G. (2010). White paper: Reconciling four models of critical thinking: FSU QEP, PaulElder, CLA and APA Delphi Fayetteville State University's Quality Enhancement Plan Writing Committee, from http://www.academia.edu/480151/Reconciling_Four_Models_of_ Critical_Thinking_FSU_QEP_Paul-Elder_CLA_and_APA_Delphi

Salomon, G., \& Perkins, D. N. (1998). Individual and social aspects of learning. In P. D. Pearson \& A. Iran-Nejad (Eds.), Review of research in education. Washington, DC: American Educational Research Association.

Scriven, M., \& Paul, R. (1987). Defining critical thinking. From http://www.criticalthinking.org/ pages/defining-critical-thinking/766

Sfard, A. (1998). On two metaphors for learning and the dangers of choosing just one. Educational Researcher, 27, 4-13.

Siegel, H. (1988). Educating reason: Rationality, critical thinking, and education. New York: Routledge.

Siegel, H. (1991). The generalizability of critical thinking. Educational Philosophy and Theory, 23, 18-30. 
Skinner, S. (1976). Cognitive development: A prerequisite for critical thinking. The Clearing House, 49, 242-299.

Strauss, V. (2012). Texas GOP rejects 'critical thinking' skills. Really. The Washington Post. Retrieved from http://www.washingtonpost.com/blogs/answer-sheet/post/texas-gop-rejectscritical-thinking-skills-really/2012/07/08/gJQAHNpFXW_blog.html

Tama, C. (1989). Critical thinking has a place in every classroom. Journal of Reading, 33, 64-65.

Tarricone, P. (2011). The taxonomy of metacognition. East Sussex, UK: Psychology Press.

Ten Dam, G., \& Volman, M. (2004). Critical thinking as citizenship competence. Learning and Instruction, 14, 259-379.

The Critical Pedagogy Collective. (2013). From http://critped.wordpress.com/

The Criticality Project. (2013). Retrieved May 17, from http://www.critical.soton.ac.uk/

Tindal, G., \& Nolet, V. (1995). Curriculum-based measurement in middle and high schools: Critical thinking skills in content areas. Focus on Exceptional Children, 27(7), 1-22.

Tishman, S., \& Andrade, A. (n.d.). Thinking dispositions: A review of current theories, practices and issues. Available at: learnweb.harvard.edu/alps/thinking/docs/Dispositions.pdf

van Gelder, T. (2005). Teaching critical thinking: Some lessons from cognitive science. College Teaching, 53(1), 41-48.

Wales, C. E., \& Nardi, A. H. (1984). The paradox of critical thinking. Morgantown, WV: Center for Guided Design.

Watson, G., \& Glaser, E. M. (2008). Watson-Glaser critical thinking appraisal. Cleveland, OH: Pearson.

Williams, R. (1976). Keywords: A vocabulary of culture and society. New York: Oxford University Press.

Willingham, D. (2007). Critical thinking: Why is it so hard to teach? American Educator, 31(2), $8-19$. 